CERE Working Paper, 2020:7

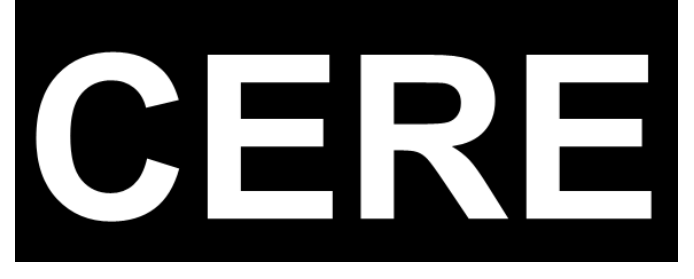

\title{
Stated benefits from urban afforestation in an arid city: A contingent valuation in Mexicali, Baja California, Mexico
}

Dalia M. Muñoz-Pizza, Mariana Villada-Canela, Patricia RiveraCastañeda, Marco A. Reyna-Carranza, Alvaro Osornio-Vargas and Adan L. Martinez-Cruz

The Centre for Environmental and Resource Economics (CERE) is an inter-disciplinary and inter-university research centre at the Umeå Campus: Umeå University and the Swedish University of Agricultural Sciences. The main objectives with the Centre are to tie together research groups at the different departments and universities; provide seminars and workshops within the field of environmental \& resource economics and management; and constitute a platform for a creative and strong research environment within the field.

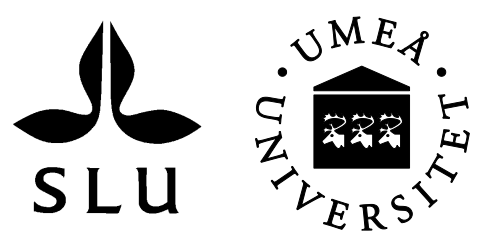




\title{
Stated benefits from urban afforestation in an arid city: A contingent valuation in Mexicali, Baja California, Mexico
}

\author{
Dalia M. Muñoz-Pizza ${ }^{\mathrm{a}}$ \\ marcela.munoz@uabc.edu.mx \\ Mariana Villada-Canela ${ }^{a}$ \\ mvilladac@uabc.edu.mx \\ Patricia Rivera-Castañeda ${ }^{\mathrm{b}}$ \\ privera@colef.mx \\ Marco A. Reyna-Carranza ${ }^{c}$ \\ mreyna@uabc.edu.mx \\ Alvaro Osornio-Vargas ${ }^{\mathrm{d}}$ \\ osornio@ualberta.ca \\ Adan L. Martínez-Cruz ${ }^{\mathrm{e}, \text {,** }}$ \\ adan.martinez.cruz@slu.se
}

${ }^{a}$ Oceanographic Research Institute. Universidad Autónoma de Baja California, Baja California, México.

${ }^{b}$ Department of Urban and Environmental Studies, El Colegio de la Frontera Norte, Baja California, México.

${ }^{c}$ Department of Bioengineering and Environmental Health, Universidad Autónoma de Baja California. Mexicali, Baja California, México.

${ }^{d}$ Department of Pediatrics, University of Alberta, Edmonton, Canada.

${ }^{e}$ Department of Forest Economics \& Centre for Environmental and Resource Economics (CERE), Swedish University of Agricultural Sciences (SLU), Umeå, Sweden.

${ }^{f}$ Department of Economics, Centro de Investigación y Docencia Económicas, Aguascalientes, México.

* Corresponding author. 


\title{
Stated benefits from urban afforestation in an arid city: A contingent valuation in Mexicali, Baja California, Mexico
}

\begin{abstract}
The pervasiveness of particulate matter in arid cities has yet to be discussed and tackled. Given that urban trees have been documented to provide air-filtering and dry deposition services, this study documents the stated benefits from an urban afforestation scenario in Mexicali -an arid city located northwest Mexico at the US-Mexico border. Our doublebounded dichotomous contingent valuation protocol yields an estimated average annual willingness to pay (WTP) of USD 88 per household. Variations in the WTP are associated with perception of air quality and presence of respiratory symptoms in the respondent's household. The smallest WTP (USD 75) is reported by respondents perceiving poor air quality in their neighborhood and with no household members affected by respiratory symptoms. In contrast, respondents perceiving good air quality and with at least one household member facing respiratory symptoms reported a WTP of USD 99. The average stated benefits represent around $0.8 \%$ of the annual household income.
\end{abstract}

Keywords: Air quality; $\mathrm{PM}_{10}$; urban afforestation; contingent valuation; arid cities; Mexicali.

JEL codes: Q51, Q53, Q58, Q59 


\section{Introduction}

Concentrations of particulate matter (PM) in arid and semi-arid cities have only recently caught the attention of policy makers at the international level (UNEP et al., 2016). Arid and semi-arid cities experience meteorological events such as extreme temperatures, low precipitation, frequent dust storms, and wind erosion processes that impede the dispersion of air pollutants (Kim et al., 2003; Ozer et al., 2006; Li et al., 2008). In these conditions, concentration of finer dust particles from sand and dust storm is exacerbated by dry conditions and reduced vegetation. Urbanization and anthropogenic emission sources also play a role. For instance, combustion of agricultural waste, road traffic, and manufacturing industries are factors that favor the formation and accumulation of atmospheric pollutants in arid and semi-arid cities (El-Fadel and Massoud, 2000; Gao et al., 2010; Massey et al., 2013; Radaideh, 2017).

Average $\mathrm{PM}_{10}$ concentrations in arid and semi-arid cities frequently surpass the World Health Organization's recommended thresholds of $20 \mu \mathrm{g} / \mathrm{m}^{3}$ annual mean and $50 \mu \mathrm{g} / \mathrm{m}^{3}$ 24-hour mean. Severe cases of $\mathrm{PM}_{10}$ pollution in the world's drylands are associated with health effects (Goudarzi, 2016). In particular, high concentrations of $\mathrm{PM}_{10}$ have been associated to morbidity and mortality due to respiratory (asthma, acute bronchitis, pneumonia, influenza, pulmonary function) and cardiovascular diseases in Xi'an (China); Tehran, Ahvaz and Kermanshah (Iran); Phoenix (US); Santiago (Chile); and West Africa (Prieto et al., 2007; De Longueville et al., 2010; Maleki et al., 2016; Wang et al., 2019; Yunesian et al., 2019). 
Also, challenges worldwide are associated with pandemics, and there is evidence in arid areas of significant correlations between, for instance, the concentrations of the virus ambient influenza A and severe dust storm episodes (Chen et al., 2010), or higher incidence rates of respiratory syncytial virus (RSV) and higher concentrations of particulate matter PM10 (Ye et al., 2016) in Hangzhou, China.

Development of strategies to fight particulate matter concentration in arid and semi-arid cities becomes urgent because i) population growth will be concentrated in cities (Buharg and Urdal, 2013); ii) global climate change will increase aridity (Gamo et al., 2013); and iii) arid and semi-arid cities are spread worldwide -including cities in Africa, southwestern Asia, northwestern India, southwestern USA, northern and central Mexico, western South America, and Australia (Hillel, 2008).

Green infrastructure is essential in reducing air pollution and increasing the increasing the social and ecological resilience of cities (Nowak, 2006). Urban trees, as part of green infrastructure, can improve air quality through air-filtering and dry deposition processes trees remove air pollution by intercepting particulate matter on plant surfaces and absorbing gaseous pollutants through the leaf stomata (Schäffler and Swilling, 2013; Terzaghi et al., 2013; Janhäll, 2015; Nowak et al., 2018).

Evidence of air-filtering service from urban trees has been studied in arid and semi-arid regions. Nowak et al. (2014) report declines in $\mathrm{PM}_{10}$ equivalent to 0.4\% (321 tons) and 0.2\% (213 tons) in Denver and Tucson due to an increase of, respectively, 26\% and 14\% in the tree coverage. Uni and Katra (2017) document a lower monthly average $\mathrm{PM}_{10}$ concentration $\left(38 \mu \mathrm{g} / \mathrm{m}^{3}\right)$ around a forest in Northern Negev, Israel, in comparison to concentrations 
measured farther away $\left(54 \mu \mathrm{g} / \mathrm{m}^{3}\right)$. Manes et al. (2016), focusing on ten Mediterranean cities, document a higher $\mathrm{PM}_{10}$ removal rate in cities with higher green coverage.

In Latin America, Escobedo and Nowak (2009) associate a reduction in $\mathrm{PM}_{10}$ in the arid region of central Chile (from 672 tons to 538 tons) to an increase in tree density (from 55.6 tree/ha to 58.2 tree/ha). In Mexico City, lower levels in annual $\mathrm{PM}_{10}$ concentration (equivalent to 100 tons) were associated to the presence of a peri-urban forest (Baumgardner et al., 2012).

The reduction in particulate matter associated to the presence of urban trees has been documented to positively impact human health (Coutts et al., 2015). A recent instance is provided by Jones and Goodkind (2019) who report a reduction in premature birth and low birth weight of 2.1 and 0.24 percentage points due to an urban afforestation program in New York City through which one million trees were planted.

Despite the documented services from urban trees, public policymakers in arid and semi-arid cities have in general overlooked urban afforestation as a strategy to combat air pollution. In part, this is due to the focus on water scarcity as the major concern in arid and semi-arid regions. In addition, urban trees are overlooked because of stakeholders' lack of awareness about how ecosystem services contribute to the functionality of a city (Escobedo et al., 2011).

This study aims to inform policy makers about the benefits from an urban afforestation scenario that would remove particulate matter via the plantation of native trees in an arid city. We take Mexicali, Baja California, as our case study. Lessons from this study are of relevance to public policy in makers in Mexico as around 65\% of Mexican territory is dryland (hyperarid, arid, semi-arid) and hosts $30 \%$ of the country's population (Becerril-Piña et al., 2015). 
In 2016, Mexicali was ranked among the cities with the highest concentration of $\mathrm{PM}_{10}$ worldwide (WHO, 2016). Several strategies have been implemented to combat air pollution in Mexicali. For instance, the latest program to improve air quality in the state of Baja California (SPA, 2018) promotes sustainable transport and agriculture, and imposes stricter regulations on the industry and vehicles. However, urban afforestation is not on the radar of public policymakers in Mexicali.

This study estimates stated benefits from urban afforestation by implementing a doublebounded contingent valuation protocol. We model the respondent's willingness to pay (WTP) as a function of the respondent's air quality perception and the presence of respiratory symptoms in the respondent's household -plus conventional characteristics reflecting respondent's and respondent household's socioeconomics. The closest exercise to this paper's is provided by Chu et al. (2020) who, to the best of our knowledge, are the only ones previously analyzing stated preferences about an afforestation program. By means of an open-ended protocol, they infer willingness to accept compensation for an afforestation of agricultural land in the Bashang Plateau, Hebei Province, China. In contrast to our study, Chu et al. (2020) have left the air filtering service from afforestation out of their focus.

This paper documents an average annual WTP of USD 88 per household. The smallest WTP (USD 75) is reported by respondents perceiving poor air quality in their neighborhood and with no household members affected by respiratory symptoms. The highest WTP (USD 99) is reported by respondents perceiving good air quality and with at least one household member facing respiratory symptoms. We have also controlled for variables capturing civic engagement and have found no significant association with WTP. 
The rest of this document has the following structure. Section 2 describes the air pollution conditions in Mexicali. The contingent valuation method is described in Section 3. Section 4 reports our data gathering strategy and descriptive statistics. Section 5 reports econometric specifications and estimated benefits. Section 6 concludes and discusses public policy recommendations.

\section{Air quality in Mexicali, Baja California}

Located at the Mexico-US border (Fig 1), Mexicali hosts 752.6 thousand inhabitants (COPLADE, 2018). Its climate is arid, with winter rainfall (around $75 \mathrm{~mm}$ annually), average high temperatures in summer (around $42.2^{\circ} \mathrm{C}$ ), and average high temperatures in winter $\left(21.1^{\circ} \mathrm{C}\right)$ (Cueto et al., 2013). Air pollution in Mexicali is caused by natural sources, emissions from the transport sector, electric power generation, industry, and unpaved streets (Rojas-Caldelas et al., 2013). Also, mineral dust resuspension and prevailing wind speed and direction (dispersion, long-range transport) are associated with high $\mathrm{PM}_{10}$ concentrations (Choi et al., 2006; Carmona et al., 2015)

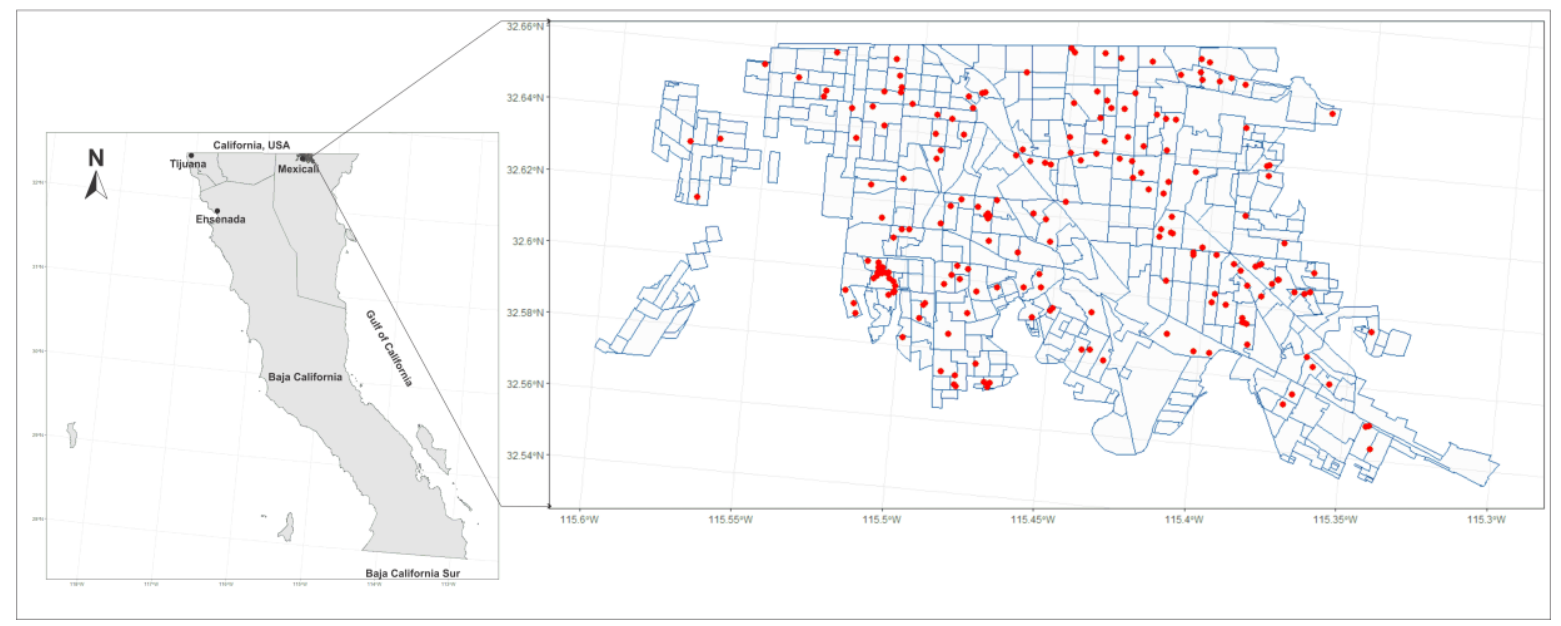


Fig 1. Location of Mexicali, Baja California, Mexico (32.55 $\left.\mathrm{N}, 115.47^{\circ} \mathrm{W}\right)$. Red dots represent respondents' place of residence.

The annual average concentration of $\mathrm{PM}_{10}$ in Mexicali has been reported as $80 \%$ higher than the national regulation before $2014\left(50 \mu \mathrm{g} \mathrm{m}^{-3}\right)$ (Zuk et al., 2007). In the last official report of air quality in Mexico, Mexicali appears with the highest annual $\mathrm{PM}_{10}$ concentrations (95 $\left.\mu \mathrm{g} \mathrm{m}^{-3}\right)$ and as the second with the highest 24-hour average $\mathrm{PM}_{10}$ concentrations $\left(274 \mu \mathrm{g} / \mathrm{m}^{3}\right)$ (INECC, 2017).

Particulate matter in Mexicali (urban and semi-urban areas) includes elements of soil mixed with metallic and non-metallic minerals from anthropogenic combustion sources. These components have been associated with hemolytic and pro-inflammatory effects (OsornioVargas et al., 2011), cardiopulmonary diseases (Silbajoris et al., 2011) and reduced lung function (Reyna et al., 2018).

Green areas per inhabitant -including recreation sport and other public services and functional green areas-roads - in Mexicali is estimated at $7.77 \mathrm{~m}^{2}$ (Peña-Salmon et al., 2014). This number is below the standard in developed countries -which is around $20 \mathrm{~m}^{2} /$ inhabitant (Wang, 2009) — and does not reach the minimum of $9 \mathrm{~m}^{2} /$ inhabitant suggested by the World Health Organization (Russo and Cirella, 2018).

\section{Valuation methodology}

Ideally, we would like to estimate the benefits from afforestation on revealed preferences data -as these data would reflect actual changes in welfare. However, urban afforestation programs are yet to be considered by policy makers aiming to improve air quality in urban 
settings. Consequently, we resort to the contingent valuation method which has been designed to deliver estimates of welfare by simulating a non-existing market.

\subsection{Previous contingent valuation studies focused on improved air quality scenarios}

Contingent valuation has extensively been used to estimate stated preferences about improved air quality scenarios. Table 1 presents a list of such studies. The first column of table 1 reports authors and year of the study. The second column reports the country or city under study. The third column describes the improved air quality scenario under valuation. The fourth column reports control variables other than the conventional respondents' socioeconomics used in the modeling of the WTP. The last column reports estimated annual WTP (in 2019 USD).

The list in table 1 illustrates three features we wish to highlight. First, previous contingent valuation studies have focused on scenarios implementing regulatory and/or technological measures to improve air quality. To the best of our knowledge, urban afforestation scenarios have yet to be on the radar of contingent valuation practitioners. A second feature that is illustrated in table 1 is the absence of particulate matter as the pollutant of interest $-\mathrm{CO}_{2}$ is the pollutant that has received the most attention so far. Consequently, we believe that the focus on $\mathrm{PM}_{10}$ is also a novelty in this contingent valuation study. The third highlight is that, when modeling respondent's WTP, previous contingent valuation studies control for whether a member in the household suffers a respiratory illness and, with less frequency, for the respondent's air quality perception. As shown in our results section, both control variables turn out to be essential in the storyline that we document in this paper.

Table 1. Studies implementing a contingent valuation protocol to estimate stated benefits from air quality improving scenarios 


\begin{tabular}{|c|c|c|c|c|}
\hline $\begin{array}{c}\text { Authors } \\
\text { (year) }\end{array}$ & $\begin{array}{l}\text { Country or } \\
\text { city under } \\
\text { study }\end{array}$ & $\begin{array}{l}\text { Improved air } \\
\text { quality scenario }\end{array}$ & $\begin{array}{c}\text { Control variables in addition to } \\
\text { socioeconomic ones" }\end{array}$ & $\begin{array}{l}\text { Reported } \\
\text { annual } \\
\text { WTP } \\
(2019 \\
\text { USD })^{* *}\end{array}$ \\
\hline $\begin{array}{l}\text { Carlsson } \\
\text { and } \\
\text { Johansson } \\
\text {-Stenman } \\
(2000)\end{array}$ & Sweden & $\begin{array}{l}50 \% \text { Reduction in } \\
\text { concentration of } \\
\text { harmful substances } \\
\text { through regulatory } \\
\text { measures }\end{array}$ & $\begin{array}{l}\text { Respondent's location (large city } \\
\text { versus smaller city), whether } \\
\text { respondent suffers a respiratory } \\
\text { illness, and respondent's } \\
\text { awareness of actual levels of } \\
\text { pollution }\end{array}$ & $\begin{array}{l}47 \text { per } \\
\text { person }\end{array}$ \\
\hline $\begin{array}{l}\text { Wang et } \\
\text { al. (2009) }\end{array}$ & $\begin{array}{l}\text { Ji'nan, } \\
\text { China }\end{array}$ & $\begin{array}{l}\text { Fulfill stringent } \\
\text { Class II air quality } \\
\text { standard through } \\
\text { technological and } \\
\text { regulatory measures }\end{array}$ & $\begin{array}{l}\text { Whether a household member } \\
\text { suffers a respiratory illness, and } \\
\text { expenditure on the treatment of } \\
\text { respiratory illness }\end{array}$ & $\begin{array}{l}15 \text { per } \\
\text { person }\end{array}$ \\
\hline $\begin{array}{l}\text { Yang et } \\
\text { al. }(2014)\end{array}$ & $\begin{array}{l}\text { Suzhou, } \\
\text { China }\end{array}$ & $\begin{array}{l}\text { Reductions of } 20 \% \text {, } \\
30 \%, 40 \% \text {, and } 45 \% \\
\text { in } \mathrm{CO}_{2} \text { emissions } \\
\text { through regulatory } \\
\text { measures }\end{array}$ & $\begin{array}{l}\text { Perceived risk from increases in } \\
\text { greenhouse gas emissions, and } \\
\text { attitudes toward government's } \\
\text { management practices (confidence } \\
\text { in policy, trust in information, } \\
\text { information disclosure) }\end{array}$ & $\begin{array}{l}56 \text { per } \\
\text { person }\end{array}$ \\
\hline $\begin{array}{l}\text { Yu et al. } \\
(2015)\end{array}$ & $\begin{array}{l}\text { North } \\
\text { China, } \\
\text { Yangtze } \\
\text { River Delta }\end{array}$ & $\begin{array}{l}\text { Reduction in } \\
\text { number of days that } \\
\text { air pollution and } \\
\text { poor visibility } \\
\text { occurs (above } 349 \\
\text { AQI), through } \\
\text { regulatory measures }\end{array}$ & $\begin{array}{l}\text { Objective visibility (through } \\
\text { monitoring of sites), respondent's } \\
\text { perception of atmospheric } \\
\text { visibility, and attitudes towards } \\
\text { environment }\end{array}$ & $\begin{array}{c}\text { Not } \\
\text { specified }\end{array}$ \\
\hline $\begin{array}{l}\text { Sun et al. } \\
(2016)\end{array}$ & $\begin{array}{l}\text { China }(30 \\
\text { provinces })\end{array}$ & $\begin{array}{l}\text { Mitigate smog } \\
\text { crisis, improve air } \\
\text { quality and reduce } \\
\text { disease caused by } \\
\text { air pollution } \\
\text { through } \\
\text { technological } \\
\text { measure (clean } \\
\text { energy generation } \\
\text { systems) }\end{array}$ & $\begin{array}{l}\text { Whether performs his/her job } \\
\text { indoors or outdoors, life } \\
\text { expectancy (whether respondent } \\
\text { believes he/she will live longer } \\
\text { than average), sources of smog } \\
\text { comes from local, household } \\
\text { annual energy expenditure } \\
\text { (including natural gas) }\end{array}$ & $\begin{array}{l}172 \text { per } \\
\text { household }\end{array}$ \\
\hline $\begin{array}{l}\text { Filippini } \\
\text { and } \\
\text { Martínez- } \\
\text { Cruz } \\
(2016)\end{array}$ & $\begin{array}{l}\text { Mexico } \\
\text { City, } \\
\text { Mexico }\end{array}$ & $\begin{array}{l}\text { Air quality } \\
\text { improvement } \\
\text { through regulatory } \\
\text { and technological } \\
\text { measures. } \\
\text { Reduction in } \\
\text { pollution would } \\
\text { save 2,200 lives and } \\
\text { avoid } 37,000 \\
\text { hospital admissions } \\
\text { annually }\end{array}$ & $\begin{array}{l}\text { Whether a household's member } \\
\text { suffers a respiratory illness, } \\
\text { concern about economic and } \\
\text { environmental issues }\end{array}$ & $\begin{array}{l}92 \text { per } \\
\text { household }\end{array}$ \\
\hline
\end{tabular}




\begin{tabular}{|c|c|c|c|c|}
\hline $\begin{array}{l}\text { Ardakani } \\
\text { et al. } \\
(2017)\end{array}$ & $\begin{array}{l}\text { Tehran, } \\
\text { Iran (Shahr- } \\
\text { e-Ray, } \\
\text { Shoosh, } \\
\text { Haft-e-Tir } \\
\text { and Tajrish) }\end{array}$ & $\begin{array}{lr}\text { Control and } \\
\text { reduction in } \\
\text { pollution in four } \\
\text { regions of Tehran }\end{array}$ & Geographic region of residence & $\begin{array}{l}9 \text { per } \\
\text { person }\end{array}$ \\
\hline $\begin{array}{l}\text { Wei and } \\
\text { Wu } \\
(2017)\end{array}$ & $\begin{array}{l}\text { JingJinJi } \\
\text { Region, } \\
\text { China }\end{array}$ & $\begin{array}{l}80 \% \text { reduction of } \\
\text { severe } \mathrm{PM}_{2.5} \\
\text { polluting days } \\
\text { through regulatory } \\
\text { measures }\end{array}$ & $\begin{array}{l}\text { Respondent`s knowledge about } \\
\text { health effects due to air pollution, } \\
\text { whether respondent believes that } \\
\text { the government should take action } \\
\text { to control air pollution, active } \\
\text { exercise at moment of survey, } \\
\text { member of communist party }\end{array}$ & $\begin{array}{c}149 \text { per } \\
\text { household }\end{array}$ \\
\hline $\begin{array}{l}\text { Akhtar et } \\
\text { al. (2017) }\end{array}$ & $\begin{array}{l}\text { Lahore, } \\
\text { Pakistan }\end{array}$ & $\begin{array}{l}50 \% \text { reduction } \\
\text { through } \\
\text { technological and } \\
\text { regulatory } \\
\text { measures. }\end{array}$ & $\begin{array}{l}\text { Respondent's subjective view } \\
\text { about air quality, whether } \\
\text { respondent suffer from a } \\
\text { respiratory illness }\end{array}$ & $\begin{array}{c}135 \text { per } \\
\text { household }\end{array}$ \\
\hline $\begin{array}{l}\text { Dong and } \\
\text { Zeng } \\
(2018)\end{array}$ & $\begin{array}{l}\text { Beijing, } \\
\text { China }\end{array}$ & $\begin{array}{l}\text { Decrease smog by } \\
30 \%, 45 \% \text { and } 60 \% \\
\text { and adhere to the } \\
\text { SCC guideline } \\
\text { value of } 35 \mu \mathrm{g} / \mathrm{m}^{3} \\
\text { through regulatory } \\
\text { measures }\end{array}$ & $\begin{array}{l}\text { Respondent's knowledge about } \\
\text { smog, risk perception of smog } \\
\text { (duration, acceptance, risk } \\
\text { feeling), attitude toward } \\
\text { government (satisfaction in policy, } \\
\text { trust in information, information } \\
\text { disclosure) }\end{array}$ & $\begin{array}{c}158 \text { per } \\
\text { household }\end{array}$ \\
\hline $\begin{array}{l}\text { Pu et al. } \\
(2019)\end{array}$ & $\begin{array}{l}\text { China (31 } \\
\text { provinces) }\end{array}$ & $\begin{array}{l}\text { Program to reduce } \\
\text { heavy air pollution } \\
\text { days by } 50 \% \text {. The } \\
\text { measures include } \\
\text { industrial energy- } \\
\text { saving and } \\
\text { emission-reduction } \\
\text { policies }\end{array}$ & $\begin{array}{l}\text { Nine variables about public's air } \\
\text { pollution. risk perception and } \\
\text { attitude: perceived risk benefit of } \\
\text { air pollution, environmental } \\
\text { awareness of protecting air quality, } \\
\text { knowledge of air pollution, } \\
\text { perceived risk about air pollution, } \\
\text { satisfaction with air quality, } \\
\text { personal protection, trust about } \\
\text { health effects due to air pollution, } \\
\text { benefit of risk management, trust } \\
\text { in future, government control trust. }\end{array}$ & $\begin{array}{l}28 \text { per } \\
\text { person }\end{array}$ \\
\hline
\end{tabular}

${ }^{*}$ Socioeconomic variables include respondent's and respondent household's characteristics such as income, education, age, gender, household size, whether house is rented or owned, etc.

${ }^{* *}$ The reported WTP has been converted to 2019 USD based on exchange rates published by the World Bank's collection of development indicators (WDI, 2019).

\subsection{Double-bounded dichotomous contingent valuation protocol}

This study gathers stated preference data by implementing a double-bounded dichotomous contingent valuation (DBDCV) protocol. In a contingent valuation protocol, once the air improving scenario is described to the respondent, the respondent is asked whether he/she 
would be willing to contribute monetarily to implement the described scenario. The DBDCV protocol presents respondent $j$ to a randomly assigned bid $\left(B_{j}^{I}\right)$ to which the respondent can answer yes or no. If his/her initial answer is yes, then a follow-up question presents the respondent to a bid $\left(B_{j}^{H}\right)$ that is higher than the initial one $\left(B_{j}^{H}>B_{j}^{I}\right)$. If his/her initial answer is no, then the follow-up question presents the respondent to a bid $\left(B_{j}^{L}\right)$ that is lower than the initial one $\left(B_{j}^{L}<B_{j}^{I}\right)$.

Consequently, respondents provide one of the following sequences of responses: i) both answers are yes $(y, y)$; ii) both answers are no $(n, n)$; iii) the initial answer is yes and the subsequent is no $(y, n)$; and iv) the initial answer is no and the subsequent is yes $(n, y)$.

Assuming that WTP is normally distributed, then an empirical distribution can be inferred by maximizing an interval-regression likelihood function (see Hanemann et al. (1991) and Lopez-Feldman (2012) for details); i.e.

$$
\begin{gathered}
\sum_{j=1}^{J}\left[d_{j}^{y y} \ln \left(\Phi\left(x_{j}^{\prime} \frac{\beta}{\sigma}-\frac{B_{j}^{H}}{\sigma}\right)\right)+d_{j}^{n n} \ln \left(1-\Phi\left(x_{j}^{\prime} \frac{\beta}{\sigma}-\frac{B_{j}^{L}}{\sigma}\right)\right)+d_{j}^{y n} \ln \left(\Phi\left(x_{j}^{\prime} \frac{\beta}{\sigma}-\frac{B_{j}^{I}}{\sigma}\right)-\Phi\left(x_{j}^{\prime} \frac{\beta}{\sigma}-\frac{B_{j}^{H}}{\sigma}\right)\right)\right. \\
\left.+d_{j}^{n y} \ln \left(\Phi\left(x_{j}^{\prime} \frac{\beta}{\sigma}-\frac{B_{j}^{L}}{\sigma}\right)-\Phi\left(x_{j}^{\prime} \frac{\beta}{\sigma}-\frac{B_{j}^{I}}{\sigma}\right)\right)\right]
\end{gathered}
$$

where $d_{j}^{y y}, d_{j}^{n n}, d_{j}^{y n}$ and $d_{j}^{n y}$ are indicators variables defining which sequence of answers where provided by respondent $j ; x_{j}$ is a vector of control variables; and $\sigma$ is the standard deviation of the normal distribution.

The DBDCV question sets out to increase the statistical efficiency of the single-bounded dichotomous contingent valuation (SBDCV) question (Hanemman et al., 1991). This increase in efficiency implies smaller samples sizes in comparison to the SBDCV protocol- 
which is a feature always welcome when it comes to carry out field work. However, the DBDCV is not free of criticism. Besides the usual issues when it comes to contingent valuation protocols -e.g. warm glow effect, anchoring, sensitivity to scope, and hypothetical bias (Carson 2012; Carson et al. 2001; Bateman et al. 2009)—, there is space for inconsistent answers to the follow-up question (Cooper et al., 2002).

\section{Materials and descriptive statistics}

\subsection{Questionnaire design and data collection}

The design of our questionnaire has accounted for the recommendations from the National Oceanic and Atmospheric Administration (NOOA) Panel (Arrow et al., 1993). In particular, adopting a face-to-face interview, pretesting, a referendum question when gathering the respondents' WTP, a thorough description of the contingent valuation scenario (including photographs). Also, some recommendations were adapted to the context of developing countries to deal with possible sources of bias. The interviewer bias was treated with training and prior explanation of each question to the interviewers, who have a background in environmental issues which is relevant to provide explanation when the surveys are implemented via face-to-face. Partial response bias was treated locating possible sensible questions such as income and education level after the WTP question. Other possible sources of bias pointed out by Riera et al. (2016) and Greenstone and Jack (2015) in developing countries are non-neutrality and complacency due to respondents' perception about potential political usage of the data. This bias was addressed assuring the respondent that the purpose of the exercise was entirely academic, and no political organization was supporting its implementation. 
Data were gathered during January 2019. The protocol was piloted on 30 respondents to define the bids presented through the double-bounded format and to polish the questions. The final instrument is composed of 36 questions. Respondents spent around 20 minutes answering it.

A total of 270 face-to-face surveys were conducted in open spaces (e.g. malls, parks, etc.) to 18 years old or older individuals. This sample size allows for representativity at the household level in Mexicali -with an error type I of $5 \%^{1}$. From the 270 surveys, 240 were fully responded and 223 include the geographical coordinates of the respondent's house. The sites and geographical coverage achieved in the final sample are presented in Fig 1.

The questionnaire is composed of five sections. ${ }^{2}$ The first section introduces the respondent to the air pollution issue in general and describes the conditions in Mexicali. We first present the respondent to a Likert-scaled question that measures awareness of environmental issues in Mexicali. Then, we explain what particulate matter is and its effects on human health. We present graphical information about the number of days in a year that $\mathrm{PM}_{10}$ concentrations surpass the national regulation in Mexicali [see Fig. S1. in Supplementary Material]. Then, urban trees are described as providing air-filtering services that can decrease $\mathrm{PM}_{10}$ concentrations and consequently improve human health.

\footnotetext{
${ }^{1}$ In research where the variable of interest is qualitative, an alpha value is usually assumed at 0.05 . The sample size formula for categorical data when the total of observational units (inhabited particular homes) are known is $n=N(Z)^{2} *(p)(q) /(d)^{2}(N-1)+(Z)^{2}(p)(q)$, where $Z=$ value for selected alpha level in each tail, in this case, 1.96, $(p)(q)=$ estimate of variance, maximum possible proportion $(0.5) * 1$ - maximum possible proportion (.5) produces maximum possible sample size. $d=$ acceptable margin of error (error researcher is willing to accept), 0.05. N=291763 inhabited particular homes, Census 2015 (INEGI, 2015). (Bartlett et al., 2001)

${ }^{2}$ The questionnaire is available from the corresponding author upon request.
} 
The second section of the survey presents the contingent valuation scenario. It is described as an urban afforestation program that would mitigate air pollution by planting native species ${ }^{3}$ _Prosopis glandulosa (mesquite dulce), Prosopis juliflora (mesquite), Acacia farnesiana (huisache) and Parkinsonia aculeate (palo verde). The potential to reduce the $\mathrm{PM}_{10}$ concentration associated with this strategy is described as a decrease between $10 \%$ to $20 \%$ in $\mathrm{PM}_{10}$ concentration - these numbers are based on results reported by studies focusing on air-filtering services from canopy species in arid and semi-arid environments (Yang et al., 2005; McDonald et al., 2016; Fares et al., 2016; Manes et al., 2016; Uni and Katra, 2017).

Before being faced to the DBDCV question, respondents were asked the following:

considering what we have previously described to you, would you be willing to contribute monetarily for the afforestation program with native trees to be maintained and expanded? The contribution is on a household and monthly basis for two years.

When the respondent responded no to this question, a follow-up question was presented so that we can identify protest zeros.

If the respondent was willing to contribute with a monetary contribution, then he/she was asked:

Would you be willing to contribute $B_{j}^{I}$ Mexican pesos? Keep in mind that this contribution is on household and monthly basis for two years.

\footnotetext{
${ }^{3}$ Native tree species have adapted to the local high temperatures and limited precipitation and therefore require less water than non-native species. Also, these species are considered ecologically relevant for arid and semiarid environments of northern Mexico (Golubov et al., 2001; Senthilkumar et al., 2005; Herrera-Arreola et al., 2007; Prasad and Tewari, 2016).
} 
If the respondent answered yes to $B_{j}^{I}$, the initial bid, then a follow-up question presented $B_{j}^{H}$, where $B_{j}^{H}>B_{j}^{I}$,

Would you be willing to contribute $B_{j}^{H}$ Mexican pesos? Keep in mind that this contribution is on household and monthly basis for two years.

If the respondent answered no to $B_{j}^{I}$, the initial bid, then a follow-up question presented $B_{j}^{L}$, where $B_{j}^{L}<B_{j}^{I}$,

Would you be willing to contribute $B_{j}^{L}$ Mexican pesos? Keep in mind that this contribution is on household and monthly basis for two years.

The definition of a vehicle payment in Mexico is particularly complicated. For instance, suggesting an increase in taxes is unrealistic and unpopular. Thus, based on what we observed in focus groups, we allowed respondents to choose their preferred vehicle payment from three alternatives -through an environmental fund administered by an NGO, water bill, or electricity bill.

The third section gathers demographic and socioeconomic information, at the individual and household levels -such as age, sex, education, household size and place of residence (zip code, neighborhood and street).

The fourth section gathers the respondent's air quality perception and health concerns. The perception of air quality is associated with the proximity to environmental risks and varies by the unit of aggregation, i.e., the perception at the neighborhood level is usually different than at the city level (Bickerstaff and Walker, 2001). To address this issue, respondents answer a five-point Likert-scaled question: "very good," "good," "regular," "poor," and "very 
poor" air quality both at the neighborhood level and at the city level. Health concern includes the knowledge of health effects and the presence of frequently respiratory symptoms in household members.

The fifth section gathers indicators of civic engagement. Civic engagement involves individual and community attitudes and behaviors related to community and political involvement, through formal (neighborhood associations) or informal (participate in walks, tree planting) relationships to address issues of public concern (Adler and Goggin, 2005; Schneider, 2007). The participation in community activities such as neighborhood meetings was measured as the ability to work for a common purpose (Paldam, 2000). On the other hand, the variable "visits to public park" in a Likert scale (frequently, occasionally, rarely, very rarely, never) was included because the use of green spaces promotes the maintenance and appropriation of these areas (Buta et al., 2014). The two variables can lead to generating awareness and influence pro-environmental behaviors (Dresner et al., 2013).

\subsection{Descriptive statistics}

Table 2 reports descriptive statistics of respondents' characteristics and perceptions. As 51 out the 240 respondents $(21 \%)$ reported a zero WTP, statistics are reported for both the entire sample $(n=240)$ and the non-zero WTP subsample $(n=189)$. Fisher's exact tests are also reported to explore whether the relative frequencies differ systematically across the entire sample and the non-zero WTP subsample. ${ }^{4}$

\footnotetext{
${ }^{4}$ The Fischer's exact test allows testing whether there is an association between two categorical variables, under the hypothesis that the row and column effects are independent in an $\mathrm{r} \times \mathrm{c}$ contingency table. This test is considered more accurate when the entries in each cell are small (Mehta and Patel, 1983).
} 
In general, Fisher's exact tests suggest that non-zero WTP respondents are fairly similar to respondents in the entire sample. The exceptions are age and perception of air quality at the neighborhood level. For the case of age, the non-zero WTP sample is composed by $55 \%$ of people older than 38 which is the median age in the entire sample. For the case of perception of air quality, the non-zero WTP sample is composed by $52 \%$ of people perceiving poor or very poor air quality at the neighborhood level -versus $48 \%$ in the entire sample. That is, a slightly higher percentage of non-zero WTP respondents are older and have poor or very poor perceptions about air quality at the neighborhood level.

Otherwise, the non-zero WTP subsample closely replicates the relative frequencies of the entire sample when it comes to i) percentage of female respondents $(61 \%)$; ii) percentage of respondents within category of education $-3 \% *$ (no school attendance), $9 \%$ (elementary school), 18\% (middle school), 26\% (high school), 35\% (bachelor), and 9\% (graduate); iii) percentage of respondents within self-reported monthly income range $-9 \%$ (< USD 136), 30\% (between USD 136 and USD 355), 27\% (between USD 355 and USD 605), 20\% (between USD 605 and USD 1,352), 5\% (between USD 1,352 and USD 1,826), 6\% (between USD 1,826 and USD 2,347), and 3\% (> USD 2,347); iv) percentage of households that own their house $(70 \%) ; \mathrm{v})$ percentage of households with more than 3 members $(50 \%)$; vi) percentage of household with at least one household member suffering respiratory symptoms (45\%); vii) percentage of respondents perceiving air quality at city level as poor or very poor (70\%); viii) percentage of respondents participating in neighborhood meetings (25\%); and ix) percentage of respondents visiting public parks (73\%). 
Table 2. Descriptive statistics of respondents' characteristics on entire sample $(n=240)$ and on sample with non-zero WTP responses $(n=189)$. Fisher's exact tests are reported to test for systematic differences.

\begin{tabular}{|c|c|c|c|c|c|}
\hline \multirow{2}{*}{ Variables } & \multirow{2}{*}{ Categories } & \multicolumn{2}{|c|}{$\begin{array}{c}\text { Entire sample } \\
n=240\end{array}$} & \multicolumn{2}{|c|}{$\begin{array}{c}\text { Non-zero WTP sample } \\
n=189\end{array}$} \\
\hline & & No. & Percentage $(\%)$ & No. & $\begin{array}{l}\text { Percentage } \\
(\%)\end{array}$ \\
\hline \multirow[t]{3}{*}{ Age Median: 38 years } & Above the median & 122 & 50 & 86 & 45 \\
\hline & Below the median & 118 & 50 & 103 & 55 \\
\hline & Fisher's exact: 0.02 & & & & \\
\hline \multirow[t]{3}{*}{ Gender } & Male & 93 & 39 & 70 & 37 \\
\hline & Female & 147 & 61 & 119 & 63 \\
\hline & Fisher's exact: 0.332 & & & & \\
\hline \multirow[t]{7}{*}{ Education } & No school attendance & 7 & 3 & 5 & 3 \\
\hline & Elementary school & 21 & 9 & 15 & 8 \\
\hline & Middle school & 44 & 18 & 35 & 19 \\
\hline & High school & 63 & 26 & 50 & 26 \\
\hline & Bachelor & 84 & 35 & 68 & 36 \\
\hline & Graduate & 21 & 9 & 16 & 8 \\
\hline & Fisher's exact test: 0.894 & & & & \\
\hline \multirow{5}{*}{$\begin{array}{l}\text { Monthly household } \\
\text { income (2019 US dollars) }\end{array}$} & $<$ USD 135.7 & 22 & 9 & 17 & 9 \\
\hline & USD 135.7 to USD 354.9 & 73 & 30 & 57 & 30 \\
\hline & USD 354.9 to USD 605.4 & 64 & 27 & 47 & 25 \\
\hline & USD 605.4 to USD 1,352 & 47 & 20 & 42 & 22 \\
\hline & UD 1,352 to USD 1,826 & 12 & 5 & 9 & 5 \\
\hline
\end{tabular}




\begin{tabular}{|c|c|c|c|c|c|}
\hline & USD 1,826 to USD 2,347 & 15 & 6 & 11 & 6 \\
\hline & $>$ USD 2,347 & 7 & 3 & 6 & 3 \\
\hline & Fisher's exact test: 0.494 & & & & \\
\hline \multirow[t]{3}{*}{ House ownership } & Yes & 168 & 70 & 127 & 67 \\
\hline & No & 72 & 30 & 62 & 33 \\
\hline & Fisher's exact test:0.085 & & & & \\
\hline \multirow{3}{*}{$\begin{array}{l}\text { Household size Median: } 3 \\
\text { members }\end{array}$} & Above the median & 120 & 50 & 94 & 50 \\
\hline & Below or equal than the median & 120 & 50 & 95 & 50 \\
\hline & Fisher's exact test: 0.500 & & & & \\
\hline \multirow{3}{*}{$\begin{array}{l}\text { Frequent respiratory } \\
\text { symptoms }^{\mathrm{a}}\end{array}$} & Yes & 108 & 45 & 87 & 46 \\
\hline & No & 132 & 55 & 102 & 54 \\
\hline & Fisher's exact: 0.635 & & & & \\
\hline \multirow{3}{*}{$\begin{array}{l}\text { Air quality perception at } \\
\text { neighborhood level }^{\text {b }}\end{array}$} & Regular-good & 124 & 52 & 91 & 48 \\
\hline & Poor- very poor & 116 & 48 & 98 & 52 \\
\hline & Fisher's exact: 0.041 & & & & \\
\hline \multirow{3}{*}{$\begin{array}{l}\text { Air quality perception at } \\
\text { city level }^{\mathrm{b}}\end{array}$} & Regular-good & 71 & 30 & 53 & 28 \\
\hline & Poor- very poor & 169 & 70 & 136 & 72 \\
\hline & Fisher's exact: 0.387 & & & & \\
\hline \multirow{3}{*}{$\begin{array}{l}\text { Participation in } \\
\text { neighborhood committees' } \\
\text { meetings }\end{array}$} & Yes & 59 & 25 & 47 & 25 \\
\hline & No & 181 & 75 & 142 & 75 \\
\hline & Fisher's exact: 0.999 & & & & \\
\hline \multirow[t]{2}{*}{ Visits to public parks ${ }^{\mathrm{c}}$} & Yes & 176 & 73 & 138 & 73 \\
\hline & No & 64 & 27 & 51 & 27 \\
\hline
\end{tabular}

Fisher's exact:0.999

$\overline{{ }^{a} \text { Cough, phlegm and difficulties of sleeping caused by coughing or wheezing mainly in children or some }}$ household member

${ }^{\mathrm{b}}$ Variables of air quality perception were dichotomized due to small observations in extreme categories

${ }^{\mathrm{c}}$ Yes, if respondent visits public parks frequently or rarely; No if respondent never visits public parks. The variable was reduced to two categories due to the small number of responses in middle categories.

\subsection{Description of zero responses}

Table 3 reports the reasons for zero WTP by category of perception of air quality at neighborhood level. The general message from table 3 is that the majority $(69 \%)$ of zero responses are protest responses. The reasons for a protest response includes lack of trust on institutions (29\%); the believe that those that pollute should be charged (16\%); that clean air 
is a human right that should not be charged for (14\%); and the opinion that more green areas are not necessary in Mexicali (4\%).

The percentage of protest responses with respect to the total sample (14\%) is below the range reported in previous studies -from $20 \%$ to $30 \%$ (Carlsson and Johansson-Stenman, 2000; Wang et al., 2015; Sun et al., 2016; Ardakani et al., 2017; Dong and Zeng, 2018). 31\% of No responses reported unwillingness to pay due to unavailable income.

Table 3. Reasons for zero WTP and perception of air quality at neighborhood level, N=51

\begin{tabular}{lllll}
\hline Reasons for zero WTP & $\begin{array}{l}\text { Poor and } \\
\text { very } \\
\text { Poor }\end{array}$ & $\begin{array}{l}\text { Regular and } \\
\text { good }\end{array}$ & Frequency & $\%$ \\
\hline Insufficient income & 11 & 5 & 16 & 31 \\
\hline Lack of trust on institutions & 11 & 4 & 15 & 29 \\
\hline $\begin{array}{l}\text { Those who pollute should be } \\
\text { charged }\end{array}$ & 4 & 4 & 8 & 16 \\
\hline Clean air is a human right & 5 & 2 & 7 & 14 \\
\hline Other reason & 1 & 2 & 3 & 6 \\
\hline $\begin{array}{l}\text { More green areas are not } \\
\text { necessary }\end{array}$ & 1 & 1 & 2 & 4 \\
\hline Total & 33 & 18 & 51 & 100 \\
\hline
\end{tabular}

\subsection{Description of answers to bids}

As illustrated in Fig. 2, three bid ranges were randomly presented to respondents -covering the range from US 2.1 to US 10.4 (2019 US dollars). The first range includes US 2.1, US 3.6, 
and US 5.2; the second, US 4.9, US 5.2, and US 8.1; and the third, US 7.1, US 8.1, and 10.4. We would expect that for each range, the percentage of yes responses monotonically decreases when the bid increases. This pattern is observed for the first and third ranges -with around $100 \%$ of yes to US $2.1,80 \%$ to US 3.6 , and $50 \%$ to US 5.2 ; and $80 \%$ to US $7.1,70 \%$ to US 8.1, and around $25 \%$ to US 10.4 . Answers to the second bid follow a non-monotonic decreasing pattern -with $70 \%$ of yes to US 4.9 and $20 \%$ to US 8.1 but around $80 \%$ to US 5.2.

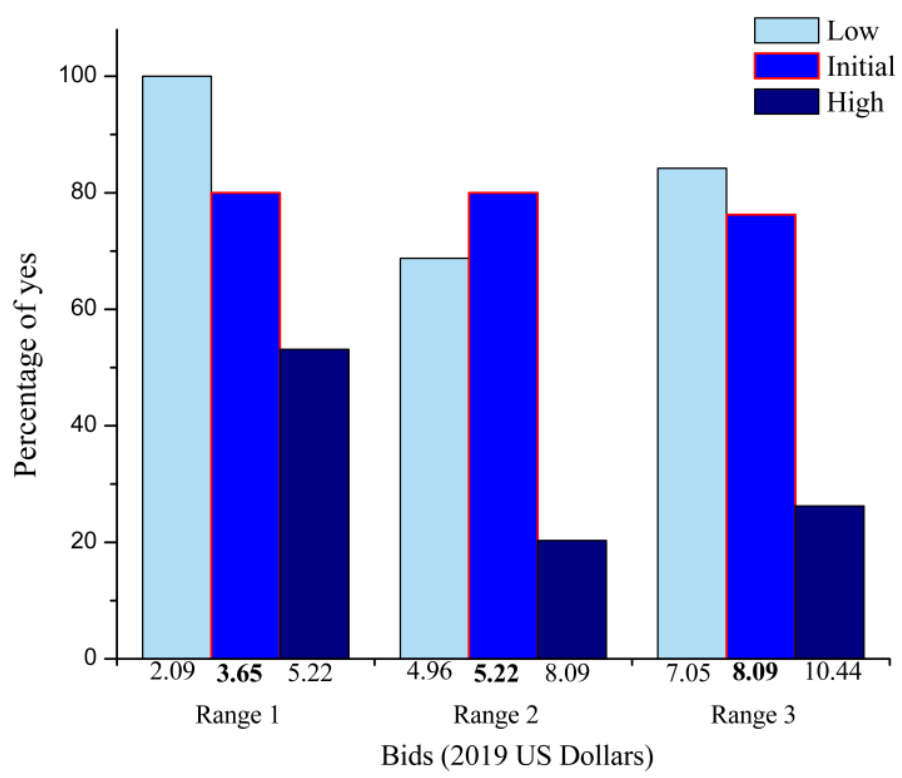

Fig 2. Percentage of yes responses to bids presented to respondents

Fig. 3 reports the relative frequencies of the preferred vehicle payment by range of bids presented to the respondents and also for the entire non-zero subsample. When focused on the entire subsample, around $20 \%$ of the respondents prefer to contribute to a fund that is created and labeled as only for afforestation purposes; around $38 \%$ of respondents prefer to contribute to funds administered by a NGO; around $26 \%$ prefer to pay via their water bill; 
and $15 \%$ prefer to pay via their electricity bill. Fig. 3 illustrates that these percentages remain relatively similar across the ranges of bids presented to respondents.

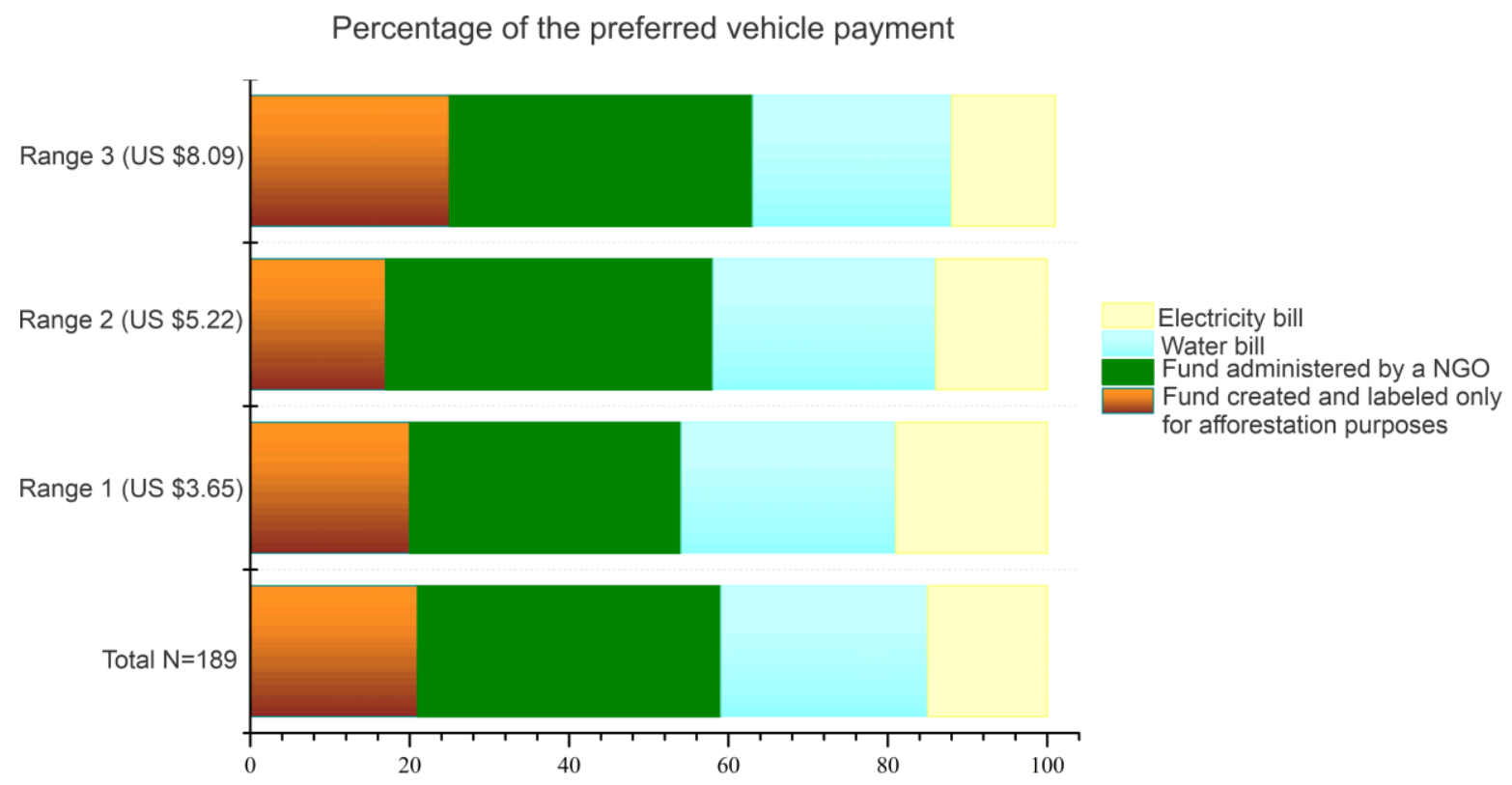

Fig 3. Relative frequencies of the preferred vehicles of payment for non-zero responses.

\section{Results}

\subsection{Econometric model}

We use the maximum likelihood estimation in Stata implemented by Lopez-Feldman (2012), which begins with a linear function for a dichotomous choice model and estimates the linear function:

$$
\operatorname{WTP}_{i}\left(x_{i}, u_{i}\right)=x_{i} \beta+u_{i}
$$

where $x_{i}$ corresponds to the control variables: socioeconomic characteristics, air quality perception, health concerns and civic engagement, $\beta$ are the estimated parameters and $u_{i}$ is the error term. 


\subsection{Econometric results}

Table 4 reports coefficients obtained via six different specifications of our double-bounded dichotomous choice (DBDC) model on the subsample of non-zero WTP respondents $(n=189)$ -we deem this appropriate as excluding the zero WTP respondents does not substantially change the composition of the sample. Specification (I) only includes the intercept, which is the (unconditional on control variables) average monthly household's WTP estimated at USD 7.44 (2019 USD) $)^{3}$. Specification (II) controls for respondents' socioeconomic variables, such as age, gender, education, and whether respondent's house is owned by the household. ${ }^{5}$ The coefficient associated with the respondent's age is statistically significant and negative. Given that this variable is dichotomous and identifies respondents 38 years old (the sample median) or older, the estimated value of its coefficient implies that respondents of 38 years old or older report a WTP that is USD 0.92 lower than respondents younger than 38 . This direction in the effect from age has been also documented by Carlsson and Johansson-Stenman (2000), Wang and Zhang (2009), Yu et al. (2015), and Wei and Yan (2017). ${ }^{6}$

Specification (III) in Table 4 builds upon the second model by adding variables capturing family concerns - a term borrowed from Filippini and Martinez-Cruz (2016). These variables include a dichotomous variable identifying the households with more than three members which is the sample median, and a dummy identifier of the households affected by frequent

\footnotetext{
5. Income is not included in our final specification due to three reasons: i) due to missing values in reported income; ii) the potential collinearity with education, and iii) income yielded insignificant coefficients when included as a control variable. We report in Table 1.A (see Supplementary Material) specifications including income-DBDC, bivariate probit and logit specifications. In these specifications, income remains insignificant, and the coefficient associated with the bidding amount remains significant and with a negative sign.

${ }^{6}$ Previous authors have also documented a lack of statistical significance for the coefficient associated to education (e.g. Wang et al., 2009; Achtnich, 2012). An explanation is that a high formal education does not necessarily imply greater environmental awareness. Torgler and Garcia-Valiñas (2007) postulated the relevance of non-formal education. The inclusion in the formal programs and diffusion of topics with orientation in the care of the environment, air pollution and health effects can have a more considerable influence.
} 
respiratory symptoms such as cough, phlegm, or sleeping problems due to respiratory complications. Specification (III) yields no significant coefficients associated to the household size. However, the self-report of the households with members experiencing respiratory symptoms yield a significant coefficient. The significance of these variable remains in specification (IV) to (VI), with coefficients around 0.86, 0.87, and 1.03, respectively. The direction of the effect is in line with results obtained by Filippini and Martinez-Cruz (2016), who also documented that respondents in households with members experiencing respiratory symptoms report a higher willingness to contribute monetarily to a program that would improve air quality in Mexico City. Also, Wang et al. (2015) and Akhtar et al. (2017) documented a positive and significant effect in Shanghai (China) and Lahore (Pakistan), respectively, for the willingness to pay to improve air quality.

Specification (IV) builds upon specification (III) by controlling for the respondent's air quality perception both at the neighborhood level and at the city level. The variables controlling perception take different values. If the respondent perceives a poor or very poor air quality at the neighborhood level, his/her WTP is smaller by around USD 0.88 (2019 USD). The direction of this effect has been previously documented by Yu et al. (2015) and Sun et al. (2016) in China for the WTP to reduce the days when air pollution and poor visibility occurs, also for smog mitigation programs. Bickerstaff (2004) associated this effect with a disconnection determined by people's perception of their ability to act, their attachment to the place and the commitment they have to neighborhood problems.

Specification (V) in Table 4 adds civic engagement proxies -a dichotomous variable identifying the respondents that visited public parks (the year previous to the survey) and a 
dichotomous variable identifying those that participate in neighborhood meetings. Both variables yield insignificant coefficients.

Specification (VI) keeps the variables that are significant in the previous specifications and the gender variable -which is kept because, in logit and bivariate probit specifications that check for robustness, gender yields statistically significant coefficients (see Table 2.A and Table 3.A in Supplementary Material). Given that statistical significance and magnitude of coefficients remain similar than in the previous five specifications, specification (VI) is our preferred one based on its overall statistical performance, as measured by the Akaike Information Criterion (AIC) -which is the smallest for specification (VI) at 518 versus values ranging 524 to 528 for the other.

The estimated intercept remains fairly similar across the six specifications reported in Table 4, which we interpret as evidence pointing out that the estimated average of WTP is robust. Also, we have carried out an alternative specification to check the robustness of the relationship between the dichotomous responses and the bids presented to the respondents. These specifications include logit models (that only model the latest response of the doublebounded dichotomous answers) and biprobit models (that model both dichotomous responses as dichotomous variables whose errors terms are correlated). The results of these models are reported in Table 2.A and Table 3.A (Supplementary Material), respectively. In general, our respondents are found to be responsive to the bids presented to them and the WTP estimates resulting from these alternative models fall within the range reported in Figure 4. 
Table 4. Double bounded dichotomous choice models on respondents with non-zero WTP $(\mathrm{n}=189)$

\begin{tabular}{|c|c|c|c|c|c|c|}
\hline Variables & $\begin{array}{l}\text { Intercept } \\
\text { (I) }\end{array}$ & $\begin{array}{l}\text { Socioeco } \\
\text { nomics } \\
\text { attributes } \\
\text { (II) }\end{array}$ & $\begin{array}{l}\text { Family } \\
\text { concerns } \\
\text { (III) }\end{array}$ & $\begin{array}{l}\text { Air quality } \\
\text { perception } \\
\text { (IV) }\end{array}$ & $\begin{array}{c}\text { Civic } \\
\text { engagement } \\
(V)\end{array}$ & $\begin{array}{l}\text { Significant } \\
\text { variables } \\
\text { (VI) }\end{array}$ \\
\hline \multicolumn{7}{|l|}{ Socioeconomic variables } \\
\hline 38 or older ${ }^{\mathrm{a}}$ & & $\begin{array}{c}-0.921 \\
(0.443) \\
* *\end{array}$ & $\begin{array}{l}-0.903 \\
(0.447) \\
* *\end{array}$ & $\begin{array}{c}-0.871 \\
(0.445) \\
* *\end{array}$ & $\begin{array}{c}-0.843 \\
(0.445) \\
*\end{array}$ & $\begin{array}{l}-0.999 \\
(0.418) \\
* *\end{array}$ \\
\hline Male $^{\mathrm{b}}$ & & $\begin{array}{c}0.446 \\
(0.442)\end{array}$ & $\begin{array}{c}0.415 \\
(0.433)\end{array}$ & $\begin{array}{c}0.488 \\
(0.431)\end{array}$ & $\begin{array}{c}0.478 \\
(0.430)\end{array}$ & $\begin{array}{c}0.485 \\
(0.430)\end{array}$ \\
\hline High education level ${ }^{\mathrm{c}}$ & & $\begin{array}{c}0.030 \\
(0.451)\end{array}$ & $\begin{array}{c}0.157 \\
(0.446)\end{array}$ & $\begin{array}{c}0.295 \\
(0.445)\end{array}$ & $\begin{array}{l}0.265 \\
(0.453)\end{array}$ & \\
\hline House ownership ${ }^{\mathrm{d}}$ & & $\begin{array}{c}0.238 \\
(0.479)\end{array}$ & $\begin{array}{c}0.122 \\
(0.471)\end{array}$ & $\begin{array}{c}0.022 \\
(0.467)\end{array}$ & $\begin{array}{c}0.044 \\
(0.468)\end{array}$ & \\
\hline \multicolumn{7}{|l|}{ Family concerns } \\
\hline $\begin{array}{l}\text { Household with more } \\
\text { than three members }\end{array}$ & & & $\begin{array}{c}0.625 \\
(0.442)\end{array}$ & $\begin{array}{c}0.538 \\
(0.439)\end{array}$ & $\begin{array}{c}0.528 \\
(0.440)\end{array}$ & \\
\hline $\begin{array}{l}\text { Household with } \\
\text { members } \\
\text { experiencing frequent } \\
\text { respiratory } \\
\text { symptoms }\end{array}$ & & & $\begin{array}{c}0.801 \\
(0.442) \\
*\end{array}$ & $\begin{array}{c}0.865 \\
(0.439) \\
* *\end{array}$ & $\begin{array}{c}0.874 \\
(0.438) \\
* *\end{array}$ & $\begin{array}{c}1.032 \\
(0.420) \\
* *\end{array}$ \\
\hline \multicolumn{7}{|c|}{ Air quality perception by geographical context ${ }^{g}$} \\
\hline $\begin{array}{l}\text { Poor or very poor air } \\
\text { quality at the } \\
\text { neighbourhood level }\end{array}$ & & & & $\begin{array}{c}-0.888 \\
(0.456) \\
*\end{array}$ & $\begin{array}{c}-0.902 \\
(0.419) \\
* *\end{array}$ & $\begin{array}{c}-0.931 \\
(0.415) \\
* *\end{array}$ \\
\hline $\begin{array}{l}\text { Poor or very poor air } \\
\text { quality at the city } \\
\text { level }\end{array}$ & & & & $\begin{array}{l}-0.060 \\
(0.504)\end{array}$ & & \\
\hline \multicolumn{7}{|c|}{ Proxies of civic engagement } \\
\hline Visits to public parks ${ }^{\mathrm{h}}$ & & & & & $\begin{array}{c}0.140 \\
(0.470)\end{array}$ & \\
\hline $\begin{array}{l}\text { Participation in } \\
\text { neighbourhood } \\
\text { meetings }{ }^{i}\end{array}$ & & & & & $\begin{array}{l}-0.231 \\
(0.476)\end{array}$ & \\
\hline Intercept & $\begin{array}{c}7.444 \\
(0.217) \\
* * *\end{array}$ & $\begin{array}{c}7.535 \\
(0.445) \\
* * *\end{array}$ & $\begin{array}{c}6.877 \\
(0.509) \\
* * *\end{array}$ & $\begin{array}{c}7.363 \\
(0.634) \\
* * *\end{array}$ & $\begin{array}{c}7.272 \\
(0.648) \\
* * *\end{array}$ & $\begin{array}{c}7.740 \\
(0.407) \\
* * *\end{array}$ \\
\hline Sigma & $\begin{array}{c}2.640 \\
(0.179) \\
* * *\end{array}$ & $\begin{array}{c}2.607 \\
(0.178) \\
* * *\end{array}$ & $\begin{array}{c}2.543 \\
(0.173) \\
* * *\end{array}$ & $\begin{array}{c}2.509 \\
(0.171) \\
* * *\end{array}$ & $\begin{array}{c}2.507 \\
(0.171) \\
* * *\end{array}$ & $\begin{array}{c}2.527 \\
(0.172) \\
* * *\end{array}$ \\
\hline LR chi2 & & $\begin{array}{c}5.26 \\
0.261\end{array}$ & $\begin{array}{l}12.73 \\
0.047\end{array}$ & $\begin{array}{l}17.56 \\
0.025\end{array}$ & $\begin{array}{c}17.87 \\
(0.037)\end{array}$ & $\begin{array}{c}15.60 \\
(0.003)\end{array}$ \\
\hline
\end{tabular}




\begin{tabular}{lcccccc}
\hline Log-likelihood & -260.809 & -258.176 & -254.518 & -252.162 & -252.011 & -253.062 \\
\hline AIC & 525.617 & 528.352 & 525.036 & 524.325 & 526.022 & 518.12 \\
\hline
\end{tabular}

Standard errors in parenthesis; $* * * \mathrm{p}<0.01, * * \mathrm{p}<0.05, * \mathrm{p}<0.1$

${ }^{a} 1$ if the respondent is older than 38 (which is the sample median); 0 , otherwise

${ }^{\mathrm{b}} 1$ if the respondent is male; 0 , female

${ }^{\mathrm{c}} 1$ if respondent attended high school or equivalent; 0 , otherwise

${ }^{\mathrm{d}} 1$ if the respondent has his/her own house; 0 , otherwise

${ }^{\mathrm{e}} 1$ if respondent's household has more than three members (which is the sample median); 0 , otherwise

${ }^{\mathrm{f}}$ Cough, phlegm and difficulties of sleeping caused by coughing or wheezing mainly in children or some household member

$\mathrm{g}_{\text {if }}$ respondent perceives that air quality is poor or very poor; 0 , if respondent perceives good that air quality is good or regular.

${ }^{\mathrm{h}} 1$ if respondent visits public parks frequently or rarely; 0 if respondent never visits public parks

${ }^{\mathrm{i}} 1$ if respondent participates in neighbourhood meetings; 0 if respondent has never participated in neighbourhood meetings.

\subsection{Estimation of the WTP}

In order to compare different scenarios, WTP was estimated based on specification (VI) and significant coefficients, including air quality perception variable and the variable of households with members frequently affected by respiratory symptoms. Fig 4. presents the WTP to improve air quality through urban afforestation under eight scenarios and take as base the estimated WTP without control variables (approximately USD 7.44). As we seek to estimate variations due to perception and health concerns, the other variables were maintained in their reference values. The estimated monthly WTP and confidence intervals were calculated with the approach suggested by Lopez-Feldman (2012).

Results in Fig 4 illustrate how point WTP estimates vary depending on air quality perception.

Keep in mind that the unconditional WTP is represented with the dotted line in Fig. 4. In all scenarios, a larger WTP prevails for the respondents who perceive air quality between good and regular in their neighborhood. Among the respondents who reported at least one member with frequent respiratory symptoms, related to allergies and respiratory diseases, the estimated WTP was higher, USD 7.79; while, WTP decreases to USD 6.69 if the respondent reports that no household member has frequent respiratory symptoms. On the other hand, 
both variables lead to the higher WTP among the respondents who perceived good air quality and a household member affected by frequently respiratory symptoms (USD 8.26). In contrast, the lower WTP corresponded to respondents without household members affected by frequently respiratory symptoms and who perceived poor air quality USD 6.29, as showed by line 1 and line 4 in the bottom box in Fig 4. Estimated WTP and 95\% confidence intervals are presented in Table 5. These scenarios suggest the importance of air quality perception in the knowledge of health effects for the design of strategies to improve air quality.

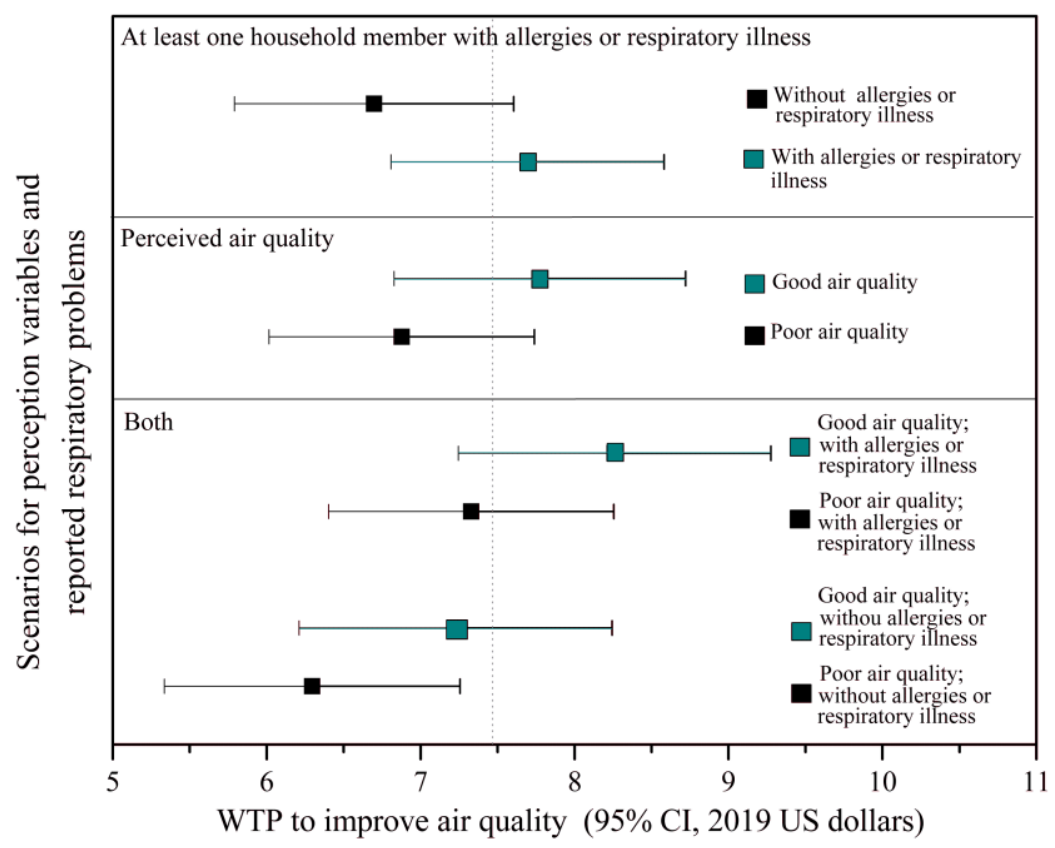

Fig 4. Estimated monthly WTP (in 2019 USD) to improve air quality by air quality perception and household members with reported respiratory problems. The dotted line corresponds to the WTP without control variables (7.44 in 2019 USD). Green color refers to the categories with a positive effect on the WTP (Good air quality perceived and household members with reported allergies or respiratory illness). Black color relates to the perception of poor air quality. 
The aggregate annual value is calculated for the specification of significant variables and the proposed scenarios (see Table 5).

Table 5. Household and aggregate WTP estimates (2019 USD) for the significant variables, scenarios of perception, and report of frequent respiratory symptoms.

\begin{tabular}{|c|c|c|c|c|}
\hline Specification & & $\begin{array}{l}\text { Monthly WTP } \\
\text { per household } \\
\text { (in } 2019 \text { USD) }\end{array}$ & $\begin{array}{l}95 \% \\
\text { Confidence } \\
\text { Interval } \\
\end{array}$ & $\begin{array}{l}\text { Annual } \\
\text { WTP (in } \\
2019 \text { USD) }\end{array}$ \\
\hline \multirow{2}{*}{$\begin{array}{l}\text { I. At least one household } \\
\text { member with frequently } \\
\text { respiratory symptoms } \\
\text { related to allergies or } \\
\text { respiratory diseases }\end{array}$} & $\begin{array}{l}\text { 1.With frequently } \\
\text { respiratory symptoms }\end{array}$ & 7.69 & $6.81-8.58$ & 92.28 \\
\hline & $\begin{array}{l}\text { 2. Without frequently } \\
\text { respiratory symptoms }\end{array}$ & 6.69 & $5.79-7.60$ & 80.28 \\
\hline \multirow[b]{2}{*}{ II. Perceived air quality } & 1. Good air quality & 7.77 & $6.83-8.72$ & 93.24 \\
\hline & 2. Poor air quality & 6.88 & $6.02-7.74$ & 82.56 \\
\hline \multirow{2}{*}{$\begin{array}{l}\text { II. Perceived air quality and } \\
\text { at least one household } \\
\text { member with frequently } \\
\text { respiratory symptoms }\end{array}$} & $\begin{array}{l}\text { 1. Good air quality; } \\
\text { with frequent } \\
\text { respiratory symptoms }\end{array}$ & 8.26 & $7.24-9.27$ & 99.12 \\
\hline & $\begin{array}{l}\text { 2. Poor air quality; } \\
\text { with frequent } \\
\text { respiratory symptoms }\end{array}$ & 7.33 & $6.40-8.25$ & 87.96 \\
\hline \multirow{2}{*}{$\begin{array}{l}\text { III. Perceived air quality and } \\
\text { without a household } \\
\text { member with frequently } \\
\text { respiratory symptoms }\end{array}$} & $\begin{array}{l}\text { 1. Good air quality; } \\
\text { without frequently } \\
\text { respiratory symptoms }\end{array}$ & 7.23 & $6.21-8.24$ & 86.76 \\
\hline & $\begin{array}{l}\text { 2. Poor air quality; } \\
\text { without frequently } \\
\text { respiratory symptoms }\end{array}$ & 6.29 & $5.33-7.26$ & 75.48 \\
\hline
\end{tabular}

Table 5 reports an average annual WTP per household of USD 87.96. We can interpret this number as the average stated benefits derived from the air-filtering service that trees would provide in Mexicali - particularly concerning $\mathrm{PM}_{10}$. Heterogeneity in the WTP is associated with perceptions of air quality and respiratory symptoms at home. Respondents that perceive poor air quality in their neighborhood and without household members affected by frequently respiratory symptoms report USD 75.48. In contrast, those perceiving good air quality and with household members with frequent respiratory symptoms report USD 99.12. 
The subset of respondents with the highest WTP (USD 99.12) represent $21 \%$ of the sample. Assuming this proportion holds for the household in Mexicali, then around 61 thousand households would receive benefits from an afforestation program of around USD 99.12 annually. This number, therefore, translates into annual benefits of around USD 6.04 million. To put in context this number, consider that between 2017 and 2018 the annual budget of the State Program in charge of providing maintenance to trees in the Mexicali municipality was USD 36.2 thousand. $^{7}$

In the context of semi-arid cities in developing countries, Escobedo et al. (2008) reported, for Santiago de Chile, a municipal urban forest management expenditure of 0.12-0.19 (2005 $\mathrm{USD} / \mathrm{m}^{2}$ ) and a cost per ton of $\mathrm{PM}_{10}$ removed by street trees of around 4.56 to $25.23 \mathrm{USD}$ thousand/ton based on an annual average removal rate of $15.9 \mathrm{~g} / \mathrm{m}^{2}$ (minimum removal rate $5.4 \mathrm{~g} / \mathrm{m}^{2}$ and maximum removal rate $29.7 \mathrm{~g} / \mathrm{m}^{2}$ ). These costs fall below the annual stated benefits that we report just based on the $21 \%$ of households in Mexicali reporting the highest WTP.

\section{Discussion}

The estimated maximum annual WTP to improve air quality through native trees in Mexicali is USD 99 (2019 USD) with a 95\% of confidence interval between USD 86 and USD 111. This amount is consistent with previous contingent studies applied to air quality improvements in Mexico. In Mexico City, the study of Filippini and Martínez-Cruz (2016) proposed regulatory and technological measures to improve air quality and the estimated annual average WTP per household was USD 92.14 (2019 USD), an amount in the range

\footnotetext{
${ }^{7}$ Private communication with public sector officials in Secretaría de Protección al Ambiente.
} 
estimated in the present study. Blackman et al. (2018), also focusing on Mexico City, report an annual WTP of USD 108.7 (2019 USD) for a regulatory measure consisting in an exemption from the day without driving program.

Fig 5 presents the annual WTP as a percentage of annual average household income from studies using both stated preferences and revealed preferences methods in Mexico. In Baja California, the annual average household income is USD 12,68 (2019 USD) (INEGI, 2019), and therefore the highest annual WTP represents $0.78 \%$ of the annual average household income. The upper part of Fig 5 shows that our estimates fall withing those reported by Filippini and Martínez-Cruz (2016) and Blackman et al. (2018) $-0.58 \%$ and 1.00\%, respectively.

Studies based on hedonic price functions report a higher WTP as a percentage of annual average household income. Rodríguez-Sánchez (2014) reports a WTP of around 1.4\% of annual household income, a value close to our estimates. Chakraborti et al. (2019) report a WTP equivalent to $2.44 \%$ of annual household income. Fontenla et al. (2019) report that an average household needs to be compensated by USD 1 thousand per year for increases in $1 \mu \mathrm{g} / \mathrm{m}^{3}$ of $\mathrm{PM}_{10}$ levels. This compensation represents around $3 \%$ of the annual average income. 


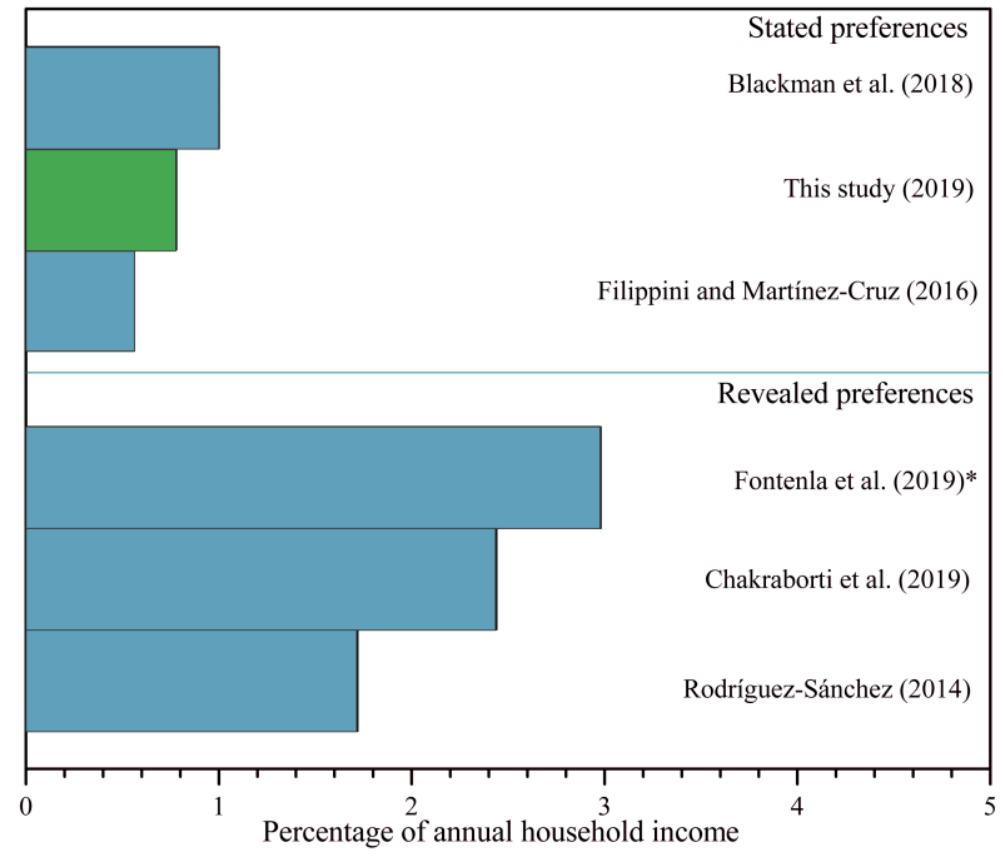

Fig 5. WTP as a percentage of annual household income to improve air quality in Mexico.

Our results imply that people report benefits large enough to recommend an urban afforestation program to improve air quality. These estimated benefits fall within values reported for other programs that also aim to improve air quality in other cities.

Indeed, in arid and semi-arid cities the water requirements (Vijayaraghan, 2016; Sadeghi et al., 2016; Azeñas et al., 2019) and some disservices associated with the potential allergenic, biogenic volatile organic compound emissions (Escobedo et al., 2011; Cariñanos, et al., 2014) can be a barrier to a successful implementation of urban afforestation programs. Robust management strategies are necessary to balance both services and disservices. A prerequisite for the development of these strategies is the assessment of the urban build environment (Abhijith et al., 2017), the potential for the rainwater management (USEPA, 2010; Feng et al., 2016) and the potential to reduce soil erosion (Jansson, 2013) as additional 
ecosystem services in arid cities, which contribute to increasing urban resilience to events associated with climate change and future virus outbreaks by decreasing the concentration of particulate matter. In this sense, the use of native tree species has been promoted in the afforestation program from cultural and scientific arguments, mainly due to reducing maintenance requirements and better qualities for PM retention of Mesquite trees (Butler et al., 2012; Préndez, 2019).

In Mexicali, Giner et al. (2019) report a reduced impact of an initiative in green infrastructure, pointing out the lack of agreement of the participating agencies on the purposes pursued with the strategy. Focus on environmental issues that already constitute problems widely recognized by the community could contribute to obtaining agreements.

Issues such as lack of trust in institutions, the strengthening of formal and informal environmental education, information on pollutant concentrations and related health effects, linked with the public perception are important factors to be strengthened by the decisionmakers. Also, Peña-Salmón (2014) pointed out the strengthening of the legal framework of urban planning in Mexico and of the technical knowledge as conditions to achieve successful strategies in afforestation urban.

\section{Conclusions}

This study contributes to a nascent literature of contingent valuation studies valuing afforestation strategies aiming to improve air quality in urban contexts. The scenario under analysis is an urban afforestation program with native trees in Mexicali, Mexico. The mean WTP per household for the proposed models was between USD 6.29 and USD 8.26 (2019 USD). The highest annual WTP estimated in this study is USD 99 (2019 USD) and represents 
around $0.8 \%$ of the annual household income. This value is close to percentages $(0.58 \%$ and $1 \%$ ) reported in previous studies that also focused on stated benefits from air improving programs in Mexico. This comparison is relevant as one of the potential criticisms to this study may arise from the exclusion of zero responses when implementing the doublebounded dichotomous specifications. We have deemed appropriate to base our estimates on only non-zero respondents because the sample that excludes zero respondents looks similar to the entire sample. Nevertheless, a reasonable suggestion is that a model allowing for selfselection should be estimated-in a similar fashion that Chu et al. (2020). However, in contrast to Chu et al. (2020), we have collected double-bounded data for which self-selection models are not readily available yet. Thus we direct the attention of the reader to the fact that the highest WTP reported on this study falls within values reported in previous studies -we refer to the highest estimates WTP because, in case of bias from self-selection, we would expect that WTP are overestimated if only based on non-zero responses.

In addition, other aspects should be considered in future work such as exploring the scope effect and exploring whether civic engagement matter at all in the context of developing countries.

The results in this study suggest the relevance of the public perception of air quality and the need to guide strategies to disseminate air quality information at small scales and expand the knowledge of the associated health effects, since the citizen's perception has an essential role in behavioral responses to strategies implemented to improve air quality. 


\section{Acknowledgements}

Authors acknowledge to PhD Hortencia Silva Jiménez, and the students Hugo Hernández Álvarez, Guadalupe Guerrero Sanchez, Santiago Lee Sánchez, Felipe Correa Ayala, Marina Mendoza Nuñez, Luis Gerardo Reyes Sánchez and Ana Karen Campa Madrid for their support in the application of the survey. The authors also would like to thank the professor Cesar Peña-Salmón for his valuable recommendations for the design of the hypothetical scenario, thought his experience in research and the practice and finally, the authors acknowledge to the official authorities from the Natural Resources Department, Secretaría de Protección al Ambiente, Baja California for the information provided. Dalia M. MunozPizza acknowledges the PhD scholarship from the Mexican Council for Science and Technology (CONACYT)

\section{References (102)}

Achtnicht, M., 2012. German car buyer's willingness to pay to reduce CO2 emissions. Clim. Chang. 113, 679-697. https://doi.org/10.1007/s10584-011-0362-8

Abhijith, K.V., Kumar, P., Gallagher, J., McNabola, A., Baldauf, R., Pilla, F., Pulvirenti, B., 2017. Air pollution abatement performances of green infrastructure in open road and builtup street canyon environments-A review. Atmos. Environ. 162, 71-86. https://doi.org/1016/j.atmosenv.2017.05.014

Adler, R.P., Goggin, J., 2005. What do we mean by “civic engagement”? J. Transform. Educ. 3, 236-253. https://doi.org/10.1177/1541344605276792

Akhtar, S., Saleem, W., Nadeem, V.M., Shahid, I., Ikram, A., 2017. Assessment of willingness to pay for improved air quality using contingent valuation method. Glob. J. Environ. Sci. Manag. 3, 279-286. http://doi.org/10.22034/gjesm.2017.03.03.005 
Ardakani, A.F., Alavi, C., Arab, M., 2017. The comparison of discrete payment vehicle methods (dichotomous choice) in improving the quality of the environment. Int. J. Environ. Sci. Technol. 14, 1490-1418. https://doi.org/10.1007/s13762-017-1264-X

Arrow, K., Solow, R., Portney, P.R., Leamer, E.E., Radner, R., Schuman, H., 1993. Report of the NOAA panel on contingent valuation. Federal register, 58(10), 4601-4614.

Azeñas V., Janner, I., Medrano, H., Gulías, J., 2019. Evaluating the establishment performance of six native perennial Mediterranean species for use in extensive green roofs under water-limiting conditions. Urban. For. Urban. Green. 41, 158-168. http://doi.org/10.1016/j.ufug.2019.04.002

Bartlett, J.E., Kotrlik, J.W., Higgins, C.C., 2001. Organizational research: Determining appropriate sample size in survey research. Information Technology, Learning, and Performance Journal 19:43-50

Bateman I.J., Day B.H., Dupont D.D., Georgiou S., 2009. Procedural invariance testing of the one-and-onehalf-bound dichotomous choice elicitation method. Rev Econ Stat 91(4):806-820

Baumgardner, D., Varela, S., Escobedo, F.J., Chacalo, A., Ochoa, C., 2012. The role of a peri-urban forest on air quality improvement in the Mexico City megalopolis. Environ. Pollut. 163, 174-183. https://doi.org/10.1016/j.envpol.2011.12.016

Blackman, A., Alpìzar, F., Carlsson, F., Planter, M.R., 2018. A contingent valuation approach to estimating regulatory costs: Mexico's day without driving program. Journal of the Association of Environmental and Resource Economists. 5, 607-641. https://doi.org/10.1086/697416

Becerril-Piña, R., Mastachi-Loza, C.A., González-Sosa, E., Díaz-Delgado, C., Bâ K.M., 2015. Assessing desertification risk in the semi-arid highlands of central Mexico. J. Arid. Environ. 120, 4-13. https://doi.org/10.1016/j.jaridenv.2015.04.006

Bickerstaff, K., Walker, G., 2001. Public understandings of air pollution: the 'localisation' of environmental risk. Glob. Environ. Chang. 11, 133-145. https://doi.org/10.1016/S09593780(00)00063-7

Bickerstaff, K., 2004. Risk perception research: socio-cultural perspectives on the public experience of air pollution. Environ. Int. 30, 827-840. https://doi.org/10.1016/j.envint.2003.12.001

Buharg, G., Urdal, H., 2013. An urbanization bomb? Population growth and social disorder in cities. Glob. Environ. Chang. 23, 1-10. https://doi.org/10.1016/j.gloenvcha.2012.10.016

Buta, N., Holland, S.M., Kaplanidou, K., 2014. Local communities and protected areas: The mediating role of place attachment for pro-environmental civic engagement. J. Outdoor Recreat. Tour. 5-6, 1-10, https://doi.org/10.1016/j.jort.2014.01.001

Butler, C., Butler, E., Orians, C.M., 2012. Native plant enthusiasm reaches new heights: perceptions, evidence, and the future of green roofs. Urban For. Urban Greening. 11, 1-10, https://doi.org/10.1016/j.ufug.2011.1 
Carmona, J.M., Vanoye, A.Y., Lozano, F., Mendoza, A., 2015. Dust emission modelling for the western border region of Mexico and the USA. Environ. Earth Sci. 74, 1687-1697. https://doi.org/10.1007/s12665-015-4173-5

Cariñanos, P., Casares-Porcel, M., Quesada-Rubio, J.M., 2014. Estimating the allergenic potential of urban green spaces: A case-study in Granada, Spain. Landsc. Urban Plan. 123, 134-144. https://doi.org/10.1016/j.landurbplan.2013.12.009

Carlsson, F., Johansson-Stenman, O., 2000. Willingness to pay for improved air quality in Sweden. Appl. Econ. 32, 661-669. https://doi.org/10.1080/000368400322273

Carson R.T., Flores N.E., Meade N.F., 2001. Contingent valuation: controversies and evidence. Env Resour Econ 19:173-210Carson, R.T., 2012. Contingent valuation: a practical alternative when prices aren't available. J Econ Perspect 26(4):27-42.

Chakraborti, L., Heres, D., Hernandez D., 2019. Are land values related to ambient air pollution levels? Hedonic evidence from Mexico City. Environ. Dev. Econ. 24, 252-270. http://doi.org/10.1017/S1355770X18000542

Chen, P.S., Tsai, F.T., Lin, C.K., Yang, C.Y., Chan, C.C., Yung, C.Y; Lee C.H. 2010. Ambient Influenza and Avian Influenza Virus during Dust Storm Days and Background Days. Environ Health Perspect 118(9):1211-1216. https://doi.org/10.1289/ehp/0901782

Choi, Y.J., Hyde P., Fernando H.J.S., 2006. Modeling of episodic particulate matter events using a 3-D air quality model with fine gride: Applications to a pair of cities in the US/Mexico border. Atmos. Environ. 40, 5181-5201. https://doi.org/10.1016/j.atmosenv.2006.04.025

Chu, X., Zhan, J., Wang, C., Hameeda, S. and Wang, X., 2020. Households' Willingness to Accept Improved Ecosystem Services and Influencing Factors: Application of Contingent Valuation Method in Bashang Plateau, Hebei Province, China. Journal of Environmental Management, 255. https://doi.org/10.1016/j.jenvman.2019.109925

Cooper, J.C., Hanemann M., Signorello G. 2002. One-and-one-half-bound Dichotomous Choice Contingent Valuation. Rev Econ Stat 84:742-50.

COPLADE, 2018. Perfil sociodemográfico del municipio de Mexicali 2018. Comité de planeación para el desarrollo del estado. Baja, California, 2018.

Coutts, C., Hahn, M., 2015. Green infrastructure, ecosystem services, and human health. Int. J Environ. Res. Public Health.12, 9768-9798. https://doi.org/10.3390/ijerph120809768

Cueto, O.G., Soto, N.S., Núñez, M.Q., Benítez, S.O., Limón, N.V., 2013. Extreme temperature scenarios in Mexicali, Mexico under climate change conditions. Atmósfera. 26, 509-520. https://doi.org/10.1016/S0187-6236(13)71092-0

Dong, K., Zeng, X., 2018. Public willingness to pay for urban smog mitigation and its determinants: A case study of Beijing, China. Atmos. Environ. 173, 355-363. https://doi.org/10.1016/j.atmosenv.2017.11.032

De Longueville, F., Hountondji Y.C., Henry, S., Ozer, P., 2010. What do we know about effects of desert dust on air quality and human health in West Africa compared to other regions? Sci. Total Environ. 409, 1-8. https://doi.org/10.1016/j.scitotenv.2010.09.025 
Dresner, M., Handelman, C., Braun, S., Rollwagen-Bollens, G., 2013. Environmental identity, pro-environmental behaviors, and civic engagement of volunteer stewards in Portland area parks. Environ. Educ. Res. 21, 991-1010https://doi.org/10.1080/13504622.2014.964188

El-Fadel, M., Massoud, M., 2000. Particulate matter in urban areas: health-based economic assessment. Sci. Total Environ. 257, 133-146. https://doi.org/10.1016/S00489697(00)00503-9

Escobedo, F.J., Wagner, J.E., Nowak, D.J., De la Maza, C.L., Rodriguez, M., Crane, D.E., 2008. Analyzing the cost effectiveness of Santiago, Chile's policy of using urban forest to improve air quality. J Environ Manage. 86: 148-157. https://doi.org/10.1016/j.jenvman.2006.11.029

Escobedo, F.J., Nowak, D.J., 2009. Spatial heterogeneity and air pollution removal by an urban forest. Landsc. Urban Plan. 90, 102-110. https://doi.org/10.1016/j.landurbplan.2008.10.021

Escobedo, F.J., Kroeger, T., Wagner, J.E., 2011. Urban forests and pollution mitigation: Analyzing ecosystem services and disservices. Environ. Pollut. 159, 2078-2087. https://doi.org/10.1016/j.envpol.2011.01.010

Fares, S., Savi, F., Fusaro, L., Conte, A., Salvatori, E., Aromolo, R., Manes, F., 2016. Particle deposition in a peri-urban Mediterranean forest. Environ. Pollut. 218, 1278-1286. https://doi.org/10.1016/j.envpol.2016.08.086

Feng, Y., Burian, S., Pomeroy, C., 2016. Potential of green infrastructure to restore predevelopment water budget of a semi-arid urban catchment. J. Hydrol. 542, 744-755. https://doi.org/10.1016/j.jhydrol.2016.09.044

Filippini, M., Martínez-Cruz, A.L., 2016. Impact of environmental and social attitudes, and family concerns on willingness to pay for improved air quality: a contingent valuation application in Mexico City. Latin Am. Econ. Rev. 25, 7. https://doi.org/10.1007/s40503-0160037-y

Fontenla M., Goodwin M.B., Gonzalez, F., 2019. Pollution and the choice of where to work and live within Mexico City. Latin Am. Econ. Rev. 28:11. https://doi.org/10.1186/s40503019-0072-6

Gao, Q., Kang, M., Xu, H., Jiang, Y., Yang, J., 2010. Optimization of land use structure and spatial pattern for the semi-arid loess hilly-gully region in China. Catena 81, 196-202. https://doi.org/10.1016/j.catena.2010.03.002

Gamo, M., Shinoda, M., Maeda, T., 2013. Classification of arid lands, including soil degradation and irrigated areas, based on vegetation and aridity indices. Int. J. Remote. Sens. 34, 6701-6722. https://doi.org/10.1080/01431161.2013.805281

Giner, M.E., Córdova, A., Vázquez-Gálvez, F.A., Marruffo, J., 2019. Promoting green infrastructure in Mexico's northern border: The Border Environment Cooperation 
Commission's experience and lessons learned. J. Environ. Manage. 248, 109104. https://doi.org/10.1016/j.jenvman.2019.06.005

Golubov, J., Mandujano, M.C., Eguiarte, L.E., 2001. The paradox of mesquites (Prosopis spp): invading species or biodiversity enhancers? Boletín de la Sociedad Botánica de México. 69, 23-30. https://doi.org/10.17129/botsci.1644

Goudarzi, G., Daryanoosh, S.M., Godini, H., Hopke, P.K., Sicard, P., De Marco, A., Rad, H.D., Harbizadeh, A., Jahedi, M.J., Mohammadi, M.J., Savari, J., Sadeghi, S., Kaabi, Z., Omidi Khaniabadi, Y., 2017. Health risk assessment of exposure to the Middle-Eastern Dust storms in the Iranian megacity of Kermanshah. Public Health. 148, 109-116. https://doi.org/10.1016/j.puhe.2017.03.009

Greenstone, M., Jack, B.K., 2015. Envirodevonomics: A research agenda for an emerging field. J. Econ. Lit. 53, 5-42. https://doi.org/10.1257/jel.53.1.5

Hanemann, M., Loomis, J., Kanninen, B., 1991. Statistical efficiency of double-bounded dichotomous choice contingent valuation. Am. J. Agr. Econ. 73, 1255-1263. https://doi.org/10.2307/1242453

Herrera-Arreola, G., Herrera, Y., Reyes-Reyes, B.G., Dendooven, L., 2007. Mesquite (Prosopis juliflora (Sw.) DC.), huisache (Acacia farnesiana (L.) Willd.) and catclaw (Mimosa biuncifera Benth) and their effect on dynamics of carbon and nitrogen in soils of the semi-arid highlands of Durango Mexico. J. Arid. Environ. 69, 583-598. http://doi.org/10.1016/j.jaridenv.2006.11.014

Hillel, D., 2008. Soil erosion and conservation. Soil in the Environment. Crucible of terrestrial life. Academic Press. 14, 197-210. http://doi.org/10.1016/B978-0-12-348536$6.50019-8$

INECC, 2018. Informe Nacional de Calidad del Aire 2017, México. Coordinación General de Contaminación y Salud Ambiental, Dirección de Investigación de Calidad del Aire y Contaminantes Climáticos. Instituto Nacional de Ecología y Cambio Climático. Ciudad de México.

INEGI, 2015. Encuesta Intercensal de Población y Vivienda 2015. Instituto Nacional de Estadística y Geografía. México. https://www.inegi.org.mx/programas/intercensal/2015/

INEGI, 2019. Encuesta Nacional de Ingresos y Gastos de los Hogares ENIGH 2019. Instituto Nacional de Estadística y Geografía, México. https://www.inegi.org.mx/programas/enigh/nc/2018/

Janhäll, S., 2015. Review on urban vegetation and particle air pollution-Deposition and dispersion. Atmos. Environ. 105, 130-137. https://doi.org/10.1016/j.atmosenv.2015.01.052

Jansson, Å, 2013. Reaching for a sustainable, resilient urban future using the lens of ecosystem services. Ecol. Econ. 86, 285-291. https://doi.org/10.1016/j.ecolecon.2012.06.013

Jones, B.A., Goodkind, A., 2019. Urban afforestation and infant health: Evidence from MillionTreesNYC. J. Environ. Econ. Manage. 95, 26-44. https://doi.org/10.1016/j.jeem.2019.03.002 
Kim, E., Larson, T.V., Hopke, P.K., Slaughter, C., Sheppard, L.E., Claiborn, C., 2003. Source identification of PM2.5 in an arid Northwest US City by positive matrix factorization. Atmos. Res. 66, 291-305. https://doi.org/10.1016/S0169-8095(03)00025-5

Li, J., Zhuang, G., Huang, K., Lin, Y., Xu, C., Yu, S., 2008. Characteristics and sources of air-borne particulate in Urumqi, China, the upstream area of Asia dust. Atmos. Environ. 42, 776-787. https://doi.org/10.1016/j.atmosenv.2007.09.062

Lopez-Feldman, A., 2012. Introduction to contingent valuation using Stata. MPRA paper 41018, Germany.

McDonald, R., Kroeger, T., Boucher, T., Wang, L., Salem, R., 2016. Planting healthy air: a global analysis of the role of urban trees in addressing particulate matter pollution and extreme heat (The Nature Conservancy, 2016).

Maleki H., Sorooshian, A., Goudarzi, G., Nikfal, A., Baneshi, M.M., 2016. Temporal profile of $\mathrm{PM}_{10}$ and associated health effects in one of the most polluted cities of the world (Ahvaz, Iran) between 2009 and 2014. Aeolian Res. 22, 135-140. https://doi.org/10.1016/j.aeolia.2016.08.006

Manes, F., Marando, F., Capotorti, G., Blasi, C., Salvatori, E., Fusaro, L., Munafò, M., 2016. Regulating Ecosystem Services of forests in ten Italian Metropolitan Cities: Air quality improvement by PM10 and O3 removal. Ecol. Indic. 67, 425-440. https://doi.org/10.1016/j.ecolind.2016.03.009

Massey, D.D., Kulshrestha, A., Taneja, A., 2013. Particulate matter concentrations and their related metal toxicity in rural residential environment of semi-arid region of India. Atmos. Environ. 67, 278-286. https://doi.org/10.1016/j.atmosenv.2012.11.002

Mehta, C.R., Patel R.N., 1983. A Network Algorithm for Performing Fisher's Exact Test in r x c Contingency Tables. Journal of the American Statistical Association. 78, 427-434. https://doi.org/10.2307/2288652

Nowak, D.J., 2006. Institutionalizing urban forestry as a "biotechnology" to improve environmental quality. Urban For. Urban Greening. 5, 93-100. https://doi.org/10.1016/j.ufug.2006.04.002

Nowak, D.J., Hirabayashi, S., Ellis, E., Greenfield, E.J., 2014. Tree and forest effects on air quality and human health in the United States. Environ. Pollut. 193, 119-129. https://doi.org/10.1016/j.envpol.2014.05.028

Nowak, D.J., Hirabayashi, S., Doyle, M., McGovern, M., Pasher, J., 2018. Air pollution removal by urban forests in Canada and its effect on air quality and human health. Urban For. Urban Greening. 29, 40-48. https://doi.org/10.1016/j.ufug.2017.10.019

Osornio-Vargas, A.R., Serrano, J., Rojas-Bracho, L., Miranda J., Garcia-Cuellar, C., Reyna, M.A., Sánchez-Pérez, Y., 2011. In vitro biological effects of airborne PM2.5 and PM10 from a semi-desert city on the Mexico-US border. Chemosphere, 83, 618-626. https://doi.org/10.1016/j.chemosphere.2010.11.073 
Ozer, P., Laghdaf, M.B.O.M., Lemines, S.O.M., Gassani, J., 2006. Estimation of air quality degradation due to Saharan dust at Nouakchott, Mauritania, from horizontal visibility data. Water Air Soil Pollut. 178, 79. https://doi.org/10.1007/s11270-006-9152-8

Paldam, M., 2000. Social capital, one or many? Definition and measurement. J. Econ. Surv. 14, 629-653. http://doi.org/10.1111/1467-6419.00127

Peña-Salmón, C., Leyva-Camacho, O., Rojas-Caldelas, R., Alonso-Navarrete, A., IñiguezAyòn, P., 2014. The identification and classification of green areas for urban planning using multispectral images at Baja California, Mexico. WIT Transactions on Ecology and the Environment, 191, 611-621. https://doi.org/10.2495/SC140511

Prasad, M.N.V., Tewari, J.C., 2016. Prosopis juliflora (Sw) DC: Potential for Bioremedation and Bioeconomy. Bioremediation and Bioeconomy. 3 46-76. https://doi.org/10.1016/B9780-12-802830-8.00003-4

Préndez, M., Araya, M., Criollo, C., Egas, C., Farías, I., Fuentealba, R., González, E., Henríquez, C., Romero, H., 2019. Urban Trees and their relationship with air pollution by particulate matter and ozone in Santiago, Chile. Urban Climates in Latin America. https://doi.org/10.1007/978-3-319-97013-4_8

Prieto M.C., Mancilla, P.F., Astudillo, P.O., Reyes, A.P., Román, O.A., 2007. Excess respiratory diseases in children and elderly people in a community of Santiago with high particulate air pollution. Revista médica de Chile. 135, 221-228. https://dx.doi.org/10.4067/S0034-98872007000200012

Pu, S., Shao, Z., Yang, L., Liu, R., Bi, J., Ma, Z., 2019. How much will the Chinese public pay for air pollution mitigation? A nationwide empirical study based on a willingness-to-pay scenario and air purifier costs. J. Clean. Prod. 218, 51-60. https://doi.org/10.1016/j.jclepro.2019.01.270

Radaideh J.A., 2017. Effect of meteorological variables on air pollutants variation in arid climates. J. Environ. Anal. Toxicol. 7, 478. https://doi.org/10.4172/2161-0525.1000478

Reyna, M.A., Mérida, J.V., Osornio-Vargas, A.R., Lerma, C., Bravo-Zanoguera, M.E., Avitia, R.L., Nieblas, E.C. 2018. Asociación entre la exposición personal a PM10 y la función pulmonar en voluntarios sanos de una ciudad semiárida en la frontera de Estados Unidos y México. Revista internacional de contaminación ambiental, 34(4), 583-595

Riera, P., Garcia D., Kriström B., Brännlund R., 2016. Manual de economía y de los recursos naturales. Valoración ambiental, Métodos de preferencias declaradas. 6, 140-141. ISBN: 978-84-283-9882-4

Rodríguez-Sánchez J.I., 2014. Do Mexicans care about air pollution? Latin Am. Econ. Rev. 23:9. https://doi.org/10.1007/s40505-014-0009-z

Rojas-Caldelas, R., Peña-Salmon, C., Corona-Zambrano, E., Arias-Vallejo, A., LeyvaCamacho, O., 2013. Environmental sustainability agenda: Metropolitan Area of Mexicali, Baja California, Mexico. WIT Transactions on Ecology and the Environment, 173, 267-277. https://doi.org/10.2495/SDP130221 
Russo, A., Cirella, G., 2018. Modern compact cities: how much greenery do we need? Int. J Environ. Res. Public Health. 15, 2180. https://doi.org/10.3390/ijerph15102180

Sadeghi, S.M.M., Attarod, P., Van Stan, J.T., Pypker, T.G., 2016. The importance of considering rainfall partitioning in afforestation initiatives in semiarid climates: A comparison of common planted tree species in Tehran, Iran. Sci. Total Environ. 568, 845855. https://doi.org/10.1016/j.scitotenv.2016.06048

Schäffler, A., Swilling, M., 2013. Valuing green infrastructure in an urban environment under pressure-The Johannesburg case. Ecol. Econ. 86, 246-257. https://doi.org/10.1016/j.ecolecon.2012.05.008

Schneider J.A., 2007. Connections and Disconnections Between Civic Engagement and Social Capital in Community-Based Nonprofits. Nonprofit and Voluntary Sector Quarterly. https://doi.org/101177/0899764006297236

SPA, 2018. Programa de Gestión para Mejorar la Calidad del Aire del Estado de Baja California 2018-2027. Secretaría de Protección al Ambiente. Baja California, México. https://www.gob.mx/semarnat/acciones-y-programas/programas-de-gestion-para-mejorarla-calidad-del-aire.

Senthilkumar, P., Prince, W.S.P.M., Sivakumar, S., Subbhuraam, C.V., 2005. Prosopis Juliflora-A green solution to decontaminate heavy metal $(\mathrm{Cu}$ and $\mathrm{Cd})$ contaminated soils. Chemosphere. 60, 1493-1496. https://doi.org/10.1016/j.chemosphere.2005.02.022

Silbajoris, R., Osornio-Vargas, A.R., Simmons, S.O., Reed, W., Bromberg, P.A., Dailey, L.A., Samet, J.M., 2011. Ambient particulate matter induces interleukin-8 expression through and alternative NF-kB (nuclear factor-kappa B) mechanism in human airway epithelial cells. Environ. Health Perspect.119, 1379-1383. https://doi.org/10.1016/j.chemosphere.2005.02.022

Sun, C., Yuan, X., Yao, X., 2016. Social acceptance towards the air pollution in China: evidence from public's willingness to pay for smog mitigation. Energy Policy. 92, 313-324. https://doi.org/10.1016/j.enpol.2016.02.025

Terzaghi, E., Wild, E., Zacchello G., Cerabolini B.E., Jones, K.C., Di Guardo, A., 2013. Forest filter effect: role of leaves in capturing/releasing air particulate matter and its $\begin{array}{lllll}\text { associated } & \text { PAHs. } & \text { Atmos. } & \text { 378-384. }\end{array}$ https://doi.org/10.1016/j.atmosenv.2013.04.013

Torgler, B., Garcia-Valiñas, M.A., 2007. The determinants of individuals' attitudes towards preventing environmental damage. Ecol. Econ. 63, 536-552. https://doi.org/10.1016/j.ecolecon.2006.12.013

UNEP, WMO, and UNCCD (2016). Global Assessment of Sand and Dust Storms. United Nations Environment Programme, Nairobi. Available at [last accessed: 11/21/2019] http://wedocs.unep.org/handle/20.500.11822/7681.

Uni, D., Katra, I., 2017. Airborne dust absorption by semi-arid forests reduces PM pollution in nearby urban environments. Sci. Total Environ. 598, 984-992. https://doi.org/10.1016/j.scitotenv.2017.04.162 
USEPA. 2010. Green Infrastructure in Arid and Semi-Arid Climates. EPA-833-B-10-002. Environmental Protection Agency. Washington, D.C, U.S.

Vijayaraghavan, K., 2016. Green roofs: a critical review on the role of components, benefits, limitations and trends. Renew. Sustainable Energy Rev. 57, 740-752. https://doi.org/10.1016/j.rser.2015.12.119

Wang, Y., Zhang, Y.S., 2009. Air quality assessment by contingent valuation in Ji'nan, China. J. Environ. Manage. 90, 1022-1029. https://doi.org/10.1016/j.jenvman.2008.03.011

Wang, X.J., 2009. Analysis of problems in urban green space system planning in China. J. For. Res. 20, 79-82. https://doi.org/10.1007/s11676-009-0014-2

Wang, K., Wu, J., Wang, R., Yang, Y., Chen, R., Maddock, J.E., Lu, Y., 2015. Analysis of residents' willingness to pay to reduce air pollution to improve children's health in community and hospital settings in Shanghai, China. Sci. Total Environ. 533, 283-289. https://doi.org/10.1016/j.scitotenv.2015.06140

Wang, L., Dong, S., Liu, M., Tao, W., Xiao, B., Zhang, S., Zhang, P., Li, X., 2019. Polycyclic aromatic hydrocarbons in atmospheric $\mathrm{PM}_{2.5}$ and $\mathrm{PM}_{10}$ in the semi-arid city of Xi'an, Northwest China: Seasonal variations, sources, health risk, and relationship with $\begin{array}{lllll}\text { meteorological } & \text { factors. } & \text { Atmos. } & \text { Res. }\end{array}$ https://doi.org/10.1016/j.atmosres.2019.06.014

WDI (2019), World Development Indicators, The World Bank Databank, https://databank.worldbank.org/reports.aspx?source=2\&series=PA.NUS.FCRF\&country=

Wei, W., Wu, Y., 2017. Willingness to pay to control PM2.5 pollution in Jing-Jin-Ji Region, China. Appl. Econ. Lett. 24, 753-761. https://doi.org/10.1080/13504851.2016.1226482

WHO, 2016. Urban Ambient Air Pollution Database-Update 2016. Summary results. Update 2016. V0.2

Yang, J., McBride, J., Zhou, J., Sun, Z., 2005. The urban forest in Beijing and its role in air pollution reduction. Urban For. Urban Greening. 3, 65-78. https://doi.org/10.1016/j.ufug.2004.09.001

Yang, J., Zou, L., Lin, T., Wu, Y., \& Wang, H. (2014). Public willingness to pay for CO2 mitigation and the determinants under climate change: a case study of Suzhou, China. Journal of environmental management, 146, 1-8.

Ye, Q., Fu J.F., Mao, J.H., Shang, S.Q. (2016). Haze is a risk factor contributing to the rapid spread of respiratory syncytial virus in children. Environmental Science and Pollution Research. 23, 20178-20185. https://doi.org/10.1007/s11356-016-7228-6

Yu, K., Chen, Z., Gao, J., Zhang, Y., Wang, S., Chai, F., 2015. Relationship between objective and subjective atmospheric visibility and its influence on willingness to accept or pay in Chine. PloS one. 10, e0139495. https://doi.org/10.1371/journal.pone.0139495 
Yunesian, M., Rostami, R., Zarei, A., Fazlzadeh, M., Janjani, H., 2019. Exposure to high levels of $\mathrm{PM}_{2.5}$ and $\mathrm{PM}_{10}$ in the metropolis of Tehran and the associated health risks during 2016-2017. Microchem, J. 150, 104174. http://doi.org/10.1016/j.micro.2019.104174

Zuk, M., Tzintzun-Cervantes, M.G., Rojas Bracho, L., 2007. Tercer almanaque de datos y tendencias de la calidad del aire en nueve ciudades mexicanas. Secretaría de Medio Ambiente y Recursos Naturales. Instituto Nacional de Ecología. México. 46-61. ISBN 978-968-817 
